\title{
Genome Mining and Enzymatic Total Biosynthesis of Purincyclamide
}

Jing Shi, ${ }^{\dagger, l}$ Xiang Xu, ${ }^{\dagger, l}$ Er Juan Zhao,${ }^{\dagger}$ Bo Zhang, ${ }^{\dagger}$ Wei Li,${ }^{\dagger}$ Yang Zhao,${ }^{\dagger}$ Rui Hua Jiao, ${ }^{*},{ }^{\dagger}$ Ren Xiang Tan, ${ }^{\dagger},+$ Hui Ming Ge ${ }^{*, \dagger}$

†State Key Laboratory of Pharmaceutical Biotechnology, Institute of Functional Biomolecules, School of Life Sciences, Nanjing University 210023, China

State Key Laboratory Cultivation Base for TCM Quality and Efficacy, Nanjing University of Chinese Medicine, Nanjing 210023, China 


\section{Table of Contents}

\section{Experimental Procedures}

General

Strain isolation and identification.

Construction of cosmid library.

Heterologous Expression and HPLC detection.

Bacterial strains and culture conditions.

Fermentation and extraction.

Isolation of compounds $\mathbf{1 - 4}$.

Construction of mutant strains.

Gene expression and protein purification.

In vitro assay of $\mathrm{PcmB} / \mathrm{PcmC}$.

In vitro assay of $\mathrm{PcmD}$.

In vitro assay of PcmE.

One-pot enzymatic total synthesis of $\mathbf{1}$.

Physiochemical data for compounds 1-4

Supplementary tables:

Table S1. Deduced functions of ORFs in the pcm gene cluster.

Table S2. Bacterial plasmids and strains.

Table S3. Primers used in this study.

Table S4. ${ }^{1} \mathrm{H}$ and ${ }^{13} \mathrm{C}$ NMR data of 1 in DMSO- $d_{6}$.

Table S5. ${ }^{1} \mathrm{H}$ and ${ }^{13} \mathrm{C}$ NMR data of 3 in DMSO- $d_{6}$.

Table S6. ${ }^{1} \mathrm{H}$ and ${ }^{13} \mathrm{C}$ NMR data of 4 in DMSO- $d_{6}$.

Supplementary figures:

Figure S1. PCR verification of pcm mutants.

Figure S2. SDS-PAGE analysis of proteins.

Figure S3. HR-ESIMS spectrum of $\mathbf{5}$.

Figure S4. The time-course of the one-pot enzymatic reaction.

Figure S5. Proposed catalytic mechanism for PcmD

Figure S6-S12. 1D and 2D NMR spectrum of 1 in DMSO- $d_{6}$.

Figure S13. ${ }^{1} \mathrm{H}$ NMR spectrum of 2 in DMSO- $d_{6}$ at $400 \mathrm{MHz}$.

Figure S14-20. 1D and 2D NMR spectrum of 3 in DMSO- $d_{6}$.

Figure S21-S26. 1D and 2D NMR spectrum of 4 in DMSO- $d_{6}$.

\section{Reference}




\section{Experimental Procedures}

\section{General.}

All 1D and 2D NMR spectra were recorded on a Bruker Avance 600 at $600 \mathrm{MHz}$ or $400 \mathrm{MHz}$ for ${ }^{1} \mathrm{H}$ and $150 \mathrm{MHz}$ or 100 $\mathrm{MHz}$ for ${ }^{13} \mathrm{C}$ nuclei. UV-vis spectra were recorded on a Nanodrop 2000 spectrometer with a $10 \mathrm{~mm}$ cuvette. High resolution mass data were run on an Agilent 6530 TOF LC/MS mass spectrometer. MPLC was conducted on a Biotage Isolera One MPLC system using a Biotage SNAP Cartridge Ultra C18 $60 \mathrm{~g}$ column. Semi-preparative HPLC was performed on an Agilent 1200 HPLC with an Agilent Eclipse XDB-C18 column $(5 \mu, 250 \times 9.4 \mathrm{~mm})$. All chemicals used in the study were of analytical grade. The enzymes for PCR were purchased form Vazyme.

\section{Strain isolation and identification.}

Strain NA04264 was isolated from an unknown insect sample collected in Zijin Mountain of Nanjing city, China. The16S rDNA gene was amplified using general primers [27F and 1492R] and sequenced. A BLAST (http://blast.ncbi.nlm.nih.gov) search of the partial 16S rRNA sequenced revealed that the closest sequence match with $99.48 \%$ identity to Streptomyces chrestomyceticus 13663Q strain (gene accession number EU741199.1).

\section{Heterologous Expression and LC-MS analysis.}

The cosmid pHG7001 was transferred into the E. coli/ET12567(pUZ8002) strain, and further introduced into $S$. albus by conjugation. ${ }^{1,2}$ The recombinant strain was grown on MS agar medium supplemented with $50 \mu \mathrm{g} / \mathrm{mL}$ apramycin for sporulation. The seed culture was prepared by inoculating fresh spores into $250-\mathrm{mL}$ baffled flasks containing $50 \mathrm{~mL}$ of TSB medium (17.0 g tryptone, $3.0 \mathrm{~g}$ soytone, $2.5 \mathrm{~g}$ glucose, $5.0 \mathrm{~g}$ sodium chloride, $2.5 \mathrm{~g} \mathrm{Na}_{2} \mathrm{HPO}_{4}$ in $1 \mathrm{~L}$ water, $\mathrm{pH} 7.0$ ) for 2 days at $28{ }^{\circ} \mathrm{C}$ and $250 \mathrm{rpm}$. Subsequently, $20 \mathrm{~mL}$ seed cultures were inoculated into $1 \mathrm{~L}$ baffled flasks containing $400 \mathrm{~mL}$ of the fermentation medium ( $10 \mathrm{~g}$ malt extract, $4 \mathrm{~g}$ yeast extract, $4 \mathrm{~g}$ glucose in $1 \mathrm{~L}$ water, $\mathrm{pH} 7.0)$, and incubated for 7 days at $160 \mathrm{rpm}$ and $30^{\circ} \mathrm{C}$. Finally, the fermentation broth was absorbed with XAD-16 resin. The resin was washed with water and eluted with methanol. The afforded methanol extract was directly used for LC-MS analysis. Each sample $(10 \mu \mathrm{L})$ was injected into the column and first eluted with a linear gradient of $10 \%$ methanol to $90 \%$ methanol in water for 13 min, and finally with $100 \%$ methanol for $3 \mathrm{~min}$ at a flow rate of $0.5 \mathrm{~mL} / \mathrm{min}$.

\section{Fermentation and extraction.}

S. albus/pHG7001 or mutant strains $(\triangle p c m B, \triangle p c m D$ or $\triangle p c m E)$ was cultured in 1-L flasks containing $200 \mathrm{~mL}$ of TSB medium. After growing at $30^{\circ} \mathrm{C}$ and $160 \mathrm{rpm}$ for 1 days, $20 \mathrm{~mL}$ of seed culture were transferred to $1 \mathrm{~L}$ flasks containing 200 $\mathrm{mL}$ of fermentation medium $(10 \mathrm{~g}$ malt extract, $4 \mathrm{~g}$ yeast extract, $4 \mathrm{~g}$ glucose in $1 \mathrm{~L}$ water, $\mathrm{pH} 7.0)$ and incubated at $30^{\circ} \mathrm{C}$ on rotary shakers $(160 \mathrm{rpm})$ for 7 days. About $4 \mathrm{~L}$ of the growth culture was filtered, absorbed with XAD-16 resin. The resin was washed with water and eluted with methanol. The methanol was removed under reduced pressure to afford crude extract.

\section{Isolation of compounds 1-4.}

For compound $\mathbf{1}$ isolation, the metabolic extract of $S$. albus/pHG7001 was fractionated by MPLC over ODS column eluted with a linear gradient $\mathrm{MeOH}-\mathrm{H}_{2} \mathrm{O}$ system from $5 \% \mathrm{MeOH}$ to $100 \% \mathrm{MeOH}$ to give twelve fractions, which were analyzed by HPLC. The fractions containing the target peak were combined and concentrated, and further fractionated by Sephadex LH20 column using $\mathrm{MeOH}$ to give several fractions. The target fraction was purified by semi-preparative HPLC with a gradient solvent system from $30 \%$ to $70 \% \mathrm{MeOH}$ in $\mathrm{H}_{2} \mathrm{O}$ system over 25 min with $2.0 \mathrm{~mL} / \mathrm{min}$ flow rate to give $\mathbf{1}(3 \mathrm{mg})$.

Compounds $2(10 \mathrm{mg}), \mathbf{3}(7 \mathrm{mg})$ and $\mathbf{4}(4 \mathrm{mg})$ were isolated from $\triangle p c m B, \Delta p c m D$ and $\Delta p c m E$ mutant strains, respectively, by using the similar procedures reported in $\mathbf{1}$ biosynthesis.

\section{Construction of mutant strains.}

The gene inactivation was performed through a $\lambda$-Red-mediated PCR-targeting mutagenesis method according to the protocol. ${ }^{3}$ In brief, primers used to amplify the disruption gene from template plasmid pIJ779 were listed in Table S3. The gene of interest on the cosmid pJTU7001 was replaced by the disruption cassette through double crossover recombination. The resulting cosmid mutant was then transformed into $S$. albus through conjugation. The genotype of individual mutant strains were verified by primers listed in Table 3 . 


\section{Gene expression and protein purification.}

For PcmE, the DNA fragment containing pcme was amplified from genomic DNA with primers listed in Table S2. The purified PCR product was ligated with linearized pET22b (linearized by NdeI and HindIII) to afford pHG7007. The plasmid pHG7007 was then transformed into E. Coli BL21(DE3) and cultivated in $400 \mathrm{~mL} \mathrm{LB}$ medium at $37^{\circ} \mathrm{C}$ until an $\mathrm{OD}_{600}$ value of 0.6 was reached. The culture was cooled to $4{ }^{\circ} \mathrm{C}$ and induced with $0.1 \mathrm{mM} \mathrm{IPTG}$, and continued to grow at $16{ }^{\circ} \mathrm{C}$ for $18 \mathrm{~h}$. fter harvesting the cells by centrifugation at $4000 \mathrm{rpm}$ for $10 \mathrm{~min}$, cells were resuspended in lysis buffer $(100 \mathrm{mM}$ Tris, $\mathrm{pH}$ 8.0, $15 \mathrm{mM}$ imidazole, $300 \mathrm{mM} \mathrm{NaCl}, 10 \%$ glycerol) and lysed on ice by sonication. After centrifugation at $15000 \mathrm{rpm}$ for $30 \mathrm{~min}$, the supernatant was filtered and purified by ÄKTA FPLC system equipped with a $5 \mathrm{~mL}$ Histrap HP column (GE lifesciences).The proteins were pooled and desalted by a PD10 column (GE Healthcare) with $100 \mathrm{mM}$ phosphate buffer (pH 7.0) and $10 \%$ glycerol and stored at $-80^{\circ} \mathrm{C}$.

Methods for overproduction and purification of PcmA, PcmB/PcmC, and PcmD were similar to that for PcmE. The plasmids and primers used for construction were listed in Table S2 and Table S3.

\section{In vitro assay of $\mathrm{PcmB} / \mathrm{PcmC}$.}

The reaction mixture $(100 \mu \mathrm{L})$ contained $1.6 \mu \mathrm{M}$ of PcmB/PcmC, $34 \mu \mathrm{M}$ of $2,2 \mathrm{mM}$ NADH in $100 \mathrm{mM}$ PBS buffer (pH 7.0). After incubation at $30{ }^{\circ} \mathrm{C}$ for $2 \mathrm{~min}$, the reaction was quenched by adding $100 \mu \mathrm{L}$ methanol. Then the mixture was centrifuged at 15,000 $\mathrm{g}$ for $10 \mathrm{~min}$ and the supernatant was analyzed by LC-MS. The LC-MS analysis was performed using a 18 min solvent gradient from $10 \%$ to $50 \%(0-20 \mathrm{~min})$ methanol in water supplied with $0.1 \mathrm{TFA}$ at a flow rate of $0.5 \mathrm{~mL} / \mathrm{min}$.

\section{In vitro assay of PcmD.}

The PcmD-catalyzed reaction was carried out in a $100 \mu \mathrm{L}$ reaction system containing $20 \mathrm{mM}$ HEPES buffer (pH 8.2), $28 \mu \mathrm{M}$ 3, $1 \mathrm{mM}$ NADPH, $9 \mu \mathrm{M}$ FDR, $30 \mu \mathrm{M}$ FDX and $8 \mu \mathrm{M} \mathrm{PcmD}$. After incubation at $30^{\circ} \mathrm{C}$ for $2 \mathrm{~h}$, the reaction was quenched by adding $100 \mu \mathrm{L}$ methanol and analyzed by LC-MS.

\section{In vitro assay of PcmE.}

A reaction mixture $(100 \mu \mathrm{L})$ containing $9.6 \mu \mathrm{M} \mathrm{PcmE}, 16.8 \mu \mathrm{M} \mathrm{4,} 100 \mu \mathrm{M}$ SAM in $20 \mathrm{mM}$ HEPES buffer (pH 8.0) was incubated at $30{ }^{\circ} \mathrm{C}$ for $2 \mathrm{~min}$. The reaction was quenched by adding $100 \mu \mathrm{L}$ methanol. After centrifugation, the supernatant was analyzed by LC-MS.

\section{One-pot enzymatic total synthesis of 1.}

A solution of $100 \mu \mathrm{M} 2$ was incubated with $1 \mu \mathrm{M}$ PcmB/C, $3 \mu \mathrm{M}$ Fdr, $10 \mu \mathrm{M}$ Fdx, $10 \mu \mathrm{M}$ PcmD, $3.2 \mu \mathrm{M}$ PcmE, $100 \mu \mathrm{M}$ $\mathrm{NADH}, 100 \mu \mathrm{M}$ NADPH and $30 \mu \mathrm{M}$ SAM in HEPES buffer $(20 \mathrm{mM}, \mathrm{pH} 8.2)$ for $10 \mathrm{~min}$. After the reaction was quenched by adding $100 \mu \mathrm{L}$ methanol, the mixture was centrifuged at 15,000 $\mathrm{g}$ for $10 \mathrm{~min}$ and the supernatant was analyzed by LC-MS.

\section{Physiochemical data for compounds 1-4}

Compound 1: white powder; NMR data see Table S4; HRESIMS $m / z$ 511.1805 [M+H]+ (calcd for $\mathrm{C}_{26} \mathrm{H}_{22} \mathrm{~N}_{8} \mathrm{O}_{4}, 511.1798$ ); $\mathrm{UV}(\mathrm{MeOH}): \lambda_{\max }(\log \varepsilon)=229$ (2.93), $314 \mathrm{~nm}(1.78)$.

Compound 2: white powder; HRESIMS m/z $350.1464[\mathrm{M}+\mathrm{H}]+$ (calcd for $\left.\mathrm{C}_{20} \mathrm{H}_{19} \mathrm{~N}_{3} \mathrm{O}_{3}, 350.1460\right) ; \mathrm{UV}(\mathrm{MeOH}): \lambda_{\max }(\log$ $\varepsilon)=230$ (2.92), $280 \mathrm{~nm}(2.63)$.

Compound 3: white powder; NMR data see Table S5; HRESIMS $m / z 348.1312[\mathrm{M}+\mathrm{H}]+\left(\right.$ calcd for $\mathrm{C}_{20} \mathrm{H}_{17} \mathrm{~N}_{3} \mathrm{O}_{3}, 348.1303$ ); $\mathrm{UV}(\mathrm{MeOH}): \lambda_{\max }(\log \varepsilon)=218$ (2.71), $285 \mathrm{~nm}(1.79), 320 \mathrm{~nm}(1.74)$.

Compound 4: white powder; NMR data see Table S6; HRESIMS $m / z 497.1650[\mathrm{M}+\mathrm{H}]+\left(\right.$ calcd for $\mathrm{C}_{25} \mathrm{H}_{20} \mathrm{~N}_{8} \mathrm{O}_{4}, 497.1641$ ); UV (MeOH): $\lambda_{\max }(\log \varepsilon)=228$ (2.91), $320 \mathrm{~nm}$ (1.95). 
Table S1. Deduced functions of ORFs in the $p c m$ gene cluster

\begin{tabular}{lllll}
\hline ORF & Amino acids $^{a}$ & Blastp homologue & Identity/coverage [\%] & Protein ID $^{b}$ \\
\hline PcmA & 256 & cyclodipeptide synthase & $98 / 100$ & EHN75269.1 \\
PcmB & 200 & cyclodipeptide oxidase & $51 / 84$ & AAN07907.1 \\
PcmC & 115 & cyclodipeptide oxidase & $49 / 78$ & AAN07908.1 \\
PcmD & 412 & cytochrome P450 & $45 / 84$ & REQ83516.1 \\
PcmE & 235 & methyltransferase & $46 / 75$ & OEV12362.1 \\
\hline
\end{tabular}

${ }^{a}$ Numbers are in amino acids. ${ }^{b}$ Given in numbers are NCBI accession numbers. GenBank accession number is MN 19076 
Table S2. Bacterial plasmids and strains.

\begin{tabular}{|c|c|c|}
\hline Plasmid/Strain & Relevant characteristics & Source \\
\hline \multicolumn{3}{|l|}{ Plasmid } \\
\hline pJTU2554 & Cosmid vector & 3 \\
\hline pET28a-(+) & $\begin{array}{l}\text { Protein expression vector used in E.coli, encoding N-terminal His-tag, kanamycin } \\
\text { resistance }\end{array}$ & Novagen \\
\hline pET22b-(+) & $\begin{array}{l}\text { Protein expression vector used in E.coli, encoding N-terminal His-tag, Ampicillin } \\
\text { resistance }\end{array}$ & Novagen \\
\hline pACYC-duet-1 & $\begin{array}{l}\text { Protein expression vector used in E.coli, encoding N-terminal His-tag, } \\
\text { Chloramphenicol resistance }\end{array}$ & Novagen \\
\hline pHG7001 & pJTU2554 harboring the intact asm gene cluster & This study \\
\hline pHG7002 & The plasmid for disruption of $\mathrm{pcmA}$ & This study \\
\hline pHG7003 & The plasmid for disruption of $p c m B$ & This study \\
\hline pHG7004 & The plasmid for disruption of $p c m C$ & This study \\
\hline pHG7005 & The plasmid for disruption of $p c m D$ & This study \\
\hline pHG7006 & pET28a(+) derived plasmid for expressing N-terminal His-tag PcmD & This study \\
\hline pHG7007 & $\mathrm{pET} 22 \mathrm{~b}(+)$ derived plasmid for expressing N-terminal His-tag PcmE & This study \\
\hline pHG7008 & pACYC-duet-1 derived plasmid for expressing PcmB and PcmC & This study \\
\hline pHG7009 & pET22b(+) derived plasmid for expressing N-terminal His-tag PcmA & This study \\
\hline pHG5008 & $\begin{array}{l}\text { pET28a(+) derived plasmid for expressing N-terminal His-tag Ctg1_1556 from } \\
\text { Kitasatospora } \mathrm{sp} \text {. CGMCC } 16924\end{array}$ & 4 \\
\hline pHG5009 & $\begin{array}{l}\text { pET28a }(+) \text { derived plasmid for expressing N-terminal His-tag Ctg1_4402 from } \\
\text { Kitasatospora } \text { sp. CGMCC } 16924\end{array}$ & 4 \\
\hline \multicolumn{3}{|l|}{ E. coli strains } \\
\hline DH5 $\alpha$ & General cloning host & 5 \\
\hline DH10B & General cloning host & \\
\hline BL21 (DE3) & Heterologous host for protein expression & NEB \\
\hline $\begin{array}{l}\text { ET12567 } \\
(\text { pUZ8002) }\end{array}$ & Methylation-deficient host used for E. coli-Streptomyces intergeneric conjugation & 6 \\
\hline \multicolumn{3}{|l|}{ Strains } \\
\hline S.albus & Model actinomycete used for gene heterologous expression. & 7 \\
\hline NA4264 & Wild type strain for purincylamide production & This study \\
\hline HG7001 & Heterologous expression of cosmid in S. albus & This study \\
\hline HG7002 & $\triangle p c m A$, in-frame deletion mutant strain & \\
\hline HG7003 & $\triangle p c m B$, in-frame deletion mutant strain & This study \\
\hline HG7004 & $\Delta p c m D$, in-frame deletion mutant strain & This study \\
\hline HG7005 & $\triangle p c m E$, in-frame deletion mutant strain & This study \\
\hline
\end{tabular}


Table S3. Primers used in this study.

\begin{tabular}{|c|c|}
\hline Name & Sequence \\
\hline screen-up-F & gttcggtgtcggccgctc \\
\hline screen-up-R & agctcatgacggagatca \\
\hline screen-down-F & ccgggcgtaggctggtgc \\
\hline screen-down-R & cgecggtcagctcctccg \\
\hline$\Delta p c m B-\mathrm{F}$ & ttcctggaactgctgcggacgcgggcggtggtgcgccgctacTGCAGCTCACGGTAACTGAT \\
\hline$\Delta p c m B-\mathrm{R}$ & ggctgtccegtcagcagtttctcceggaccgccgtacgccgcTGTAGGCTGGAGCTGCTTC \\
\hline$\Delta p c m D-\mathrm{F}$ & gcgtggctggtgtccacctacgagctggccacccgcgtcetgTGCAGCTCACGGTAACTGAT \\
\hline$\Delta p c m D-\mathrm{R}$ & gatgctgatgtccaggcegctcatcagccgecgecagtcgtcTGTAGGCTGGAGCTGCTTC \\
\hline$\triangle p c m E-\mathrm{F}$ & ccgtacggcagagaggcegcgcgagtggccgatcaagtcgccTGCAGCTCACGGTAACTGAT \\
\hline$\Delta p c m E-\mathrm{R}$ & gcgggccagcgccgagacgaacaccggctcgggaaggttcatTGTAGGCTGGAGCTGCTTC \\
\hline pcmB-YZ-F & ggacgccactactgeccg \\
\hline pcmB-YZ-R & gacgttcagcagtgccgg \\
\hline pcmD-YZ-F & gacaaccaggcgttcctg \\
\hline pcmD-YZ-R & gagcagcagcatgatcgc \\
\hline pcmE-YZ-F & gatcttcgcgecetgecc \\
\hline pcmE-YZ-R & gtgagatgagggcgaggc \\
\hline duet-PcmB-m1-F & CACAGCCAGGATCCGAATTCGgtgacetgtcecgecggg \\
\hline duet-PcmB-m1-R & GCATTATGCGGCCGCAAGCTTtcatcggtcaggtccggtg \\
\hline duet-PcmC-m2-F & GTATAAGAAGGAGATATACATATGgcacctggacacccccgg \\
\hline duet-PcmC-m2-R & CGGTTTCTTTACCAGACTCGAGtcagcectcggcaggecc \\
\hline PcmD-pET28a-F & GTGCCGCGCGGCAGCCATATGagcggacagcctcccgg \\
\hline PcmD-pET28a-R & GCTCGAGTGCGGCCGCAAGCTTtcaccagagcaccggcag \\
\hline PcmE-pET22b-F & AAGAAGGAGATATACATATGaagcgcatcgggaaaggc \\
\hline PcmE-pET22b-R & CTCGAGTGCGGCCGCAAGCTTcccggagtgagatgaggg \\
\hline PcmA-pET22b-F & AAGAAGGAGATATACATATGggtgcgcegcaggct \\
\hline PcmA-pET22b-R & CTCGAGTGCGGCCGCAAGCTTcgtcacgtccetttctcc \\
\hline
\end{tabular}


Table S4. ${ }^{1} \mathrm{H}$ and ${ }^{13} \mathrm{C}$ NMR data of $\mathbf{1}$ in DMSO- $d_{6}$.
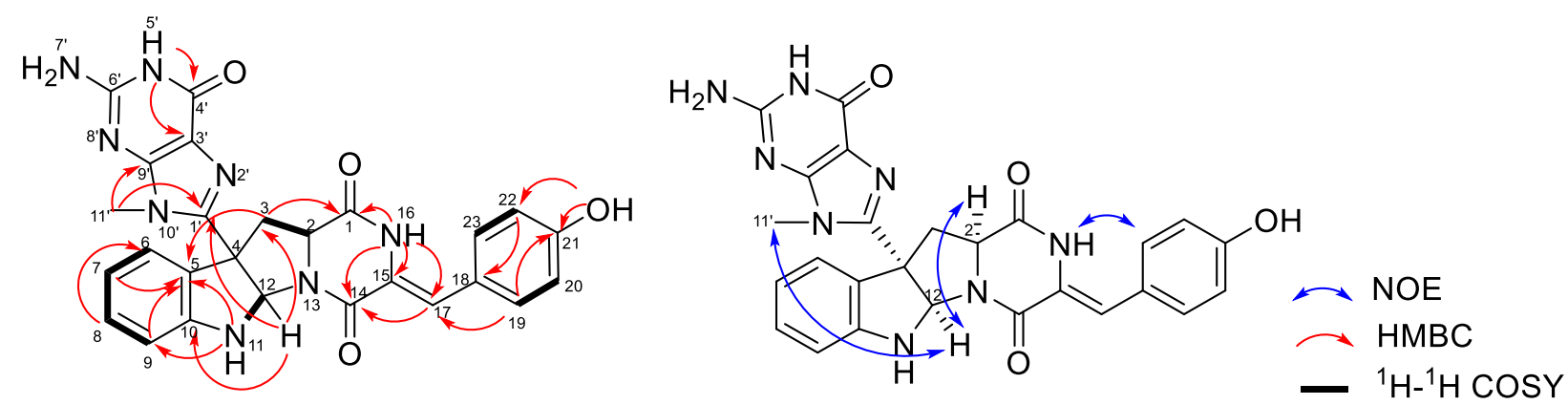

\begin{tabular}{|c|c|c|}
\hline No. & $\delta_{\mathrm{C}}$ & $\delta_{\mathrm{H}}($ mult $, J, \mathrm{~Hz})$ \\
\hline 1 & $167.2, \mathrm{C}$ & \\
\hline 2 & $57.9, \mathrm{CH}$ & $4.69(\mathrm{dd}, 12.0,6.0)$ \\
\hline 3 & $40.5, \mathrm{CH}_{2}$ & $3.80(\mathrm{dd}, 12.0,6.0), 2.00(\mathrm{t}, 12.0)$ \\
\hline 4 & $56.0, \mathrm{C}$ & \\
\hline 5 & $130.1, \mathrm{C}$ & \\
\hline 6 & $122.9, \mathrm{CH}$ & $6.83(\mathrm{dd}, 8.4,2.0)$ \\
\hline 7 & $118.8, \mathrm{CH}$ & $6.63(\mathrm{t}, 8.4)$ \\
\hline 8 & $129.6, \mathrm{CH}$ & $7.10(\mathrm{t}, 8.4)$ \\
\hline 9 & $109.9, \mathrm{CH}$ & $6.66(\mathrm{dd}, 8.4,2.0)$ \\
\hline 10 & 149.3, C & \\
\hline $11-\mathrm{NH}$ & & $7.25(\mathrm{~d}, 3.6)$ \\
\hline 12 & $81.0, \mathrm{CH}$ & $5.91(\mathrm{~d}, 3.6)$ \\
\hline 14 & 161.2, C & \\
\hline 15 & 126.1, C & \\
\hline $16-\mathrm{NH}$ & & $10.01(\mathrm{~s})$ \\
\hline 17 & $117.4, \mathrm{CH}$ & $6.68(\mathrm{~s})$ \\
\hline 18 & $124.6, \mathrm{C}$ & \\
\hline 19 & $131.8, \mathrm{CH}$ & $7.43(\mathrm{~d}, 8.4)$ \\
\hline 20 & $115.9, \mathrm{CH}$ & $6.79(\mathrm{~d}, 8.4)$ \\
\hline 21 & $158.3, \mathrm{C}$ & \\
\hline 22 & $115.9, \mathrm{CH}$ & $6.79(\mathrm{~d}, 8.4)$ \\
\hline 23 & $131.8, \mathrm{CH}$ & $7.43(\mathrm{~d}, 8.4)$ \\
\hline 1 , & $146.6, \mathrm{C}$ & $3.06(\mathrm{~s})$ \\
\hline $3^{\prime}$ & $115.0, \mathrm{C}$ & \\
\hline 4 ' & 157.0, C & \\
\hline $5^{\prime}-\mathrm{NH}$ & & $10.6(\mathrm{~s})$ \\
\hline $6^{\prime}$ & 154.2, C & \\
\hline 9' & $154.0, \mathrm{C}$ & \\
\hline $11^{\prime}$ & $29.6, \mathrm{CH}_{3}$ & $3.02(\mathrm{~s})$ \\
\hline
\end{tabular}


Table S5. ${ }^{1} \mathrm{H}$ and ${ }^{13} \mathrm{C}$ NMR data of 3 in DMSO- $d_{6}$.

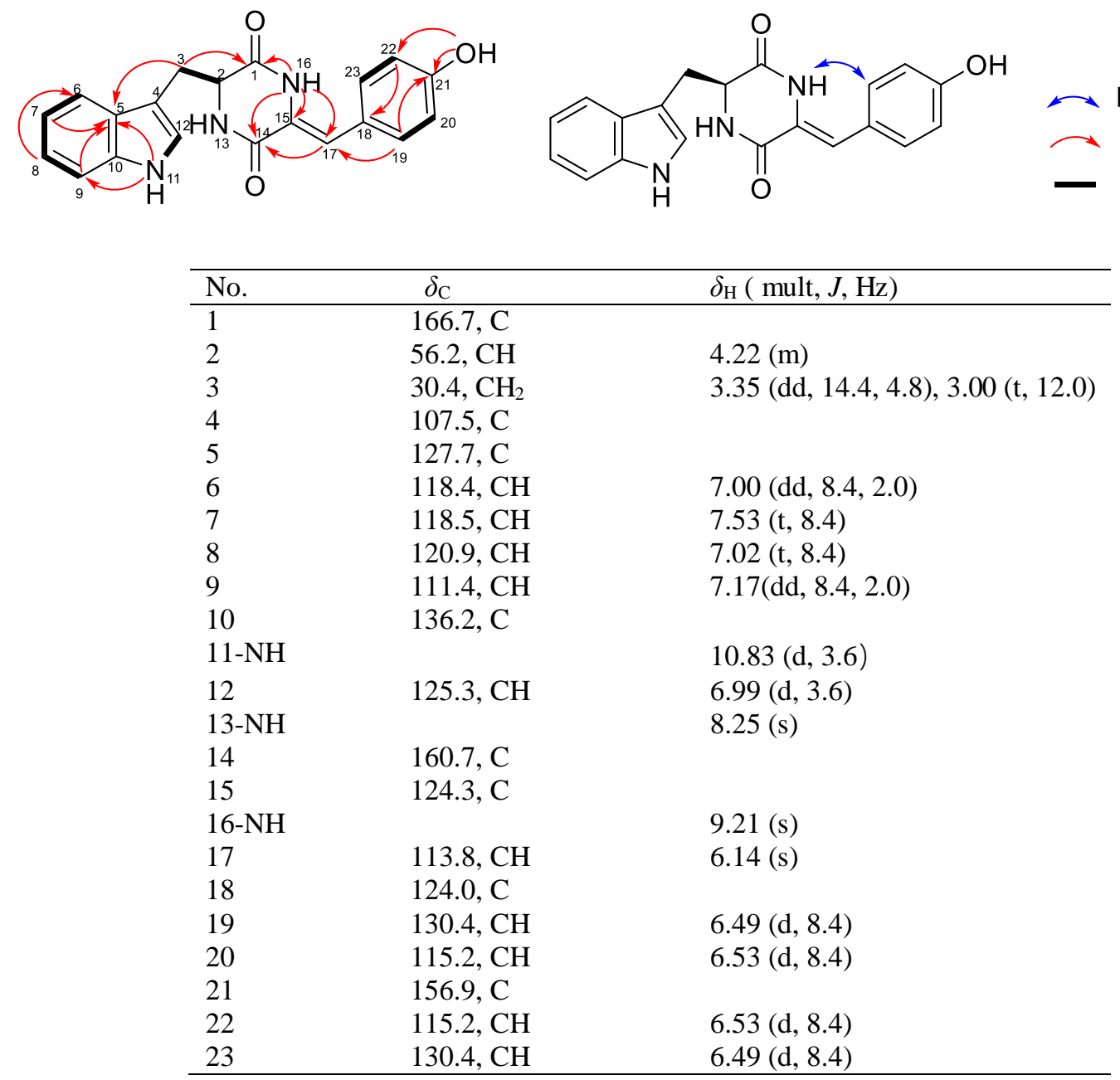


Table S6. ${ }^{1} \mathrm{H}$ and ${ }^{13} \mathrm{C}$ NMR data of 4 in DMSO- $d_{6} .{ }^{a}$

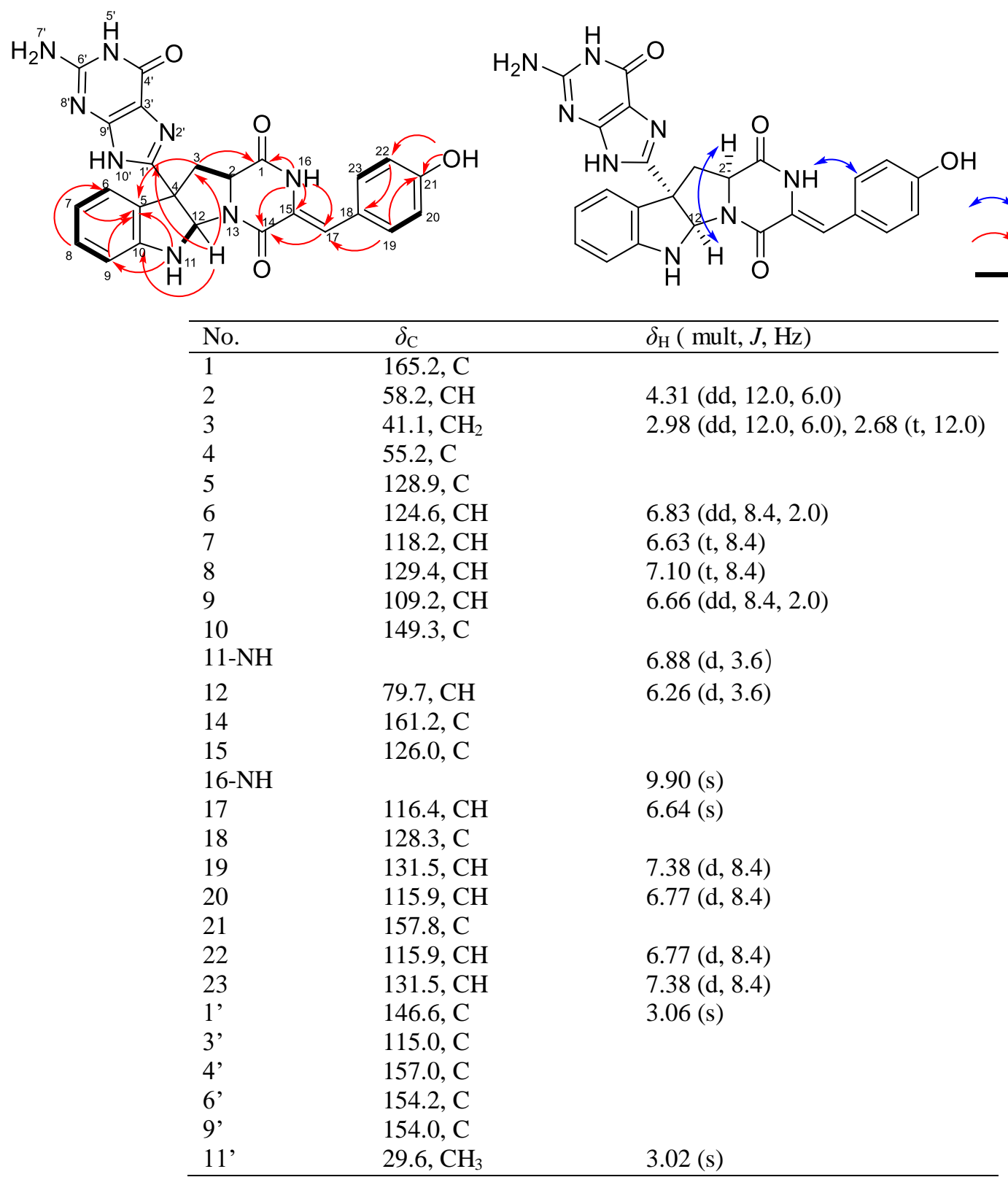


A)

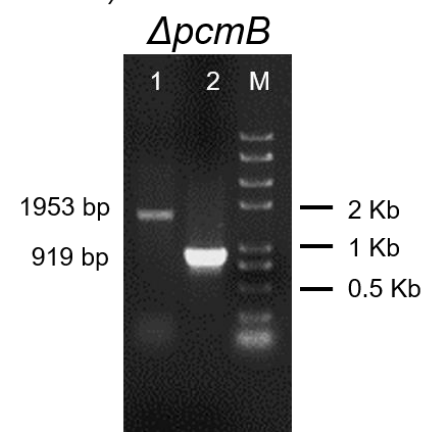

B)

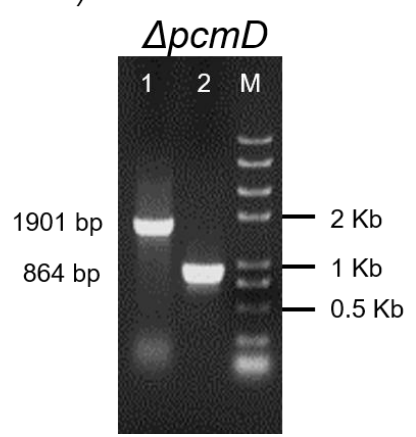

C)

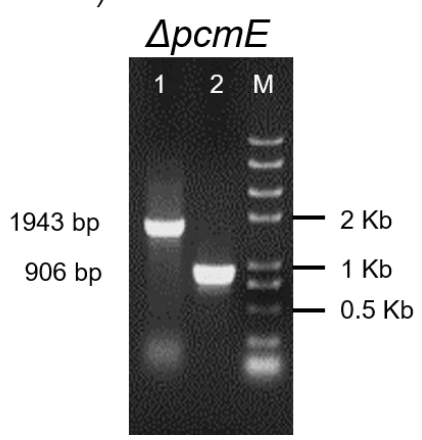

Figure S1. PCR verification for gene mutants. A) Lane1, amplified with pcmB-YZ-F/R and $\Delta p c m B$; Lane 2, amplified with pcmB-YZ-F/R and cosmid pHG7001. B) Lane1, amplified with pcmD-YZ-F/R and $\triangle p c m D$; Lane 2, amplified with pcmDYZ-F/R and cosmid pHG7001. C) Lane1, amplified with pcmE-YZ-F/R and $\triangle p c m E$; Lane 2, amplified with pcmE-YZ-F/R and cosmid pHG7001.

A)

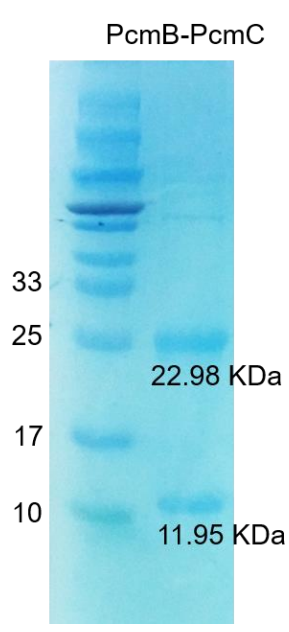

B)

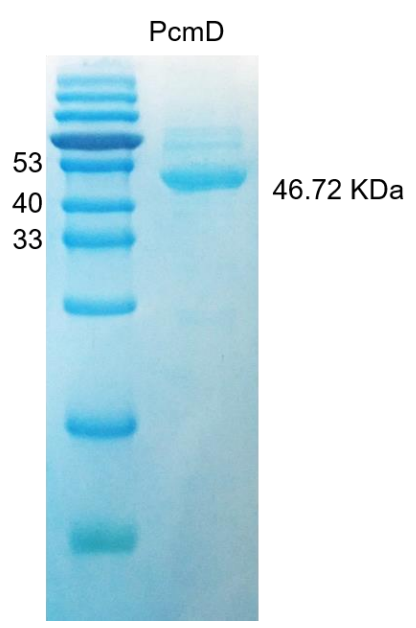

C)

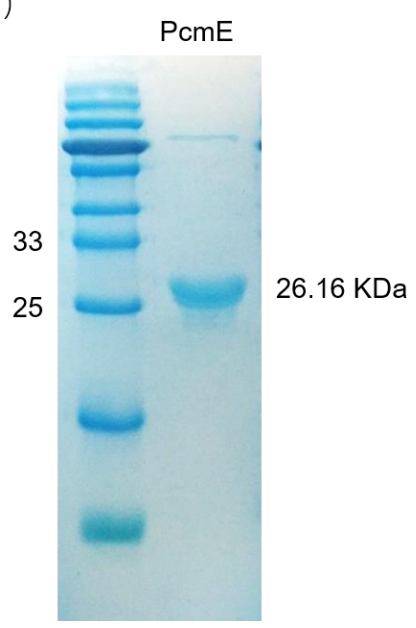

Figure S2. SDS-PAGE analysis of proteins. A) PcmB and PcmC (calculated molecule weight $22.98 \mathrm{KDa}$ and 11.95KDa); B) PcmD (calculated molecule weight $46.72 \mathrm{KDa}$ ); C) PcmE (calculated molecule weight: $26.16 \mathrm{KDa}$ ).

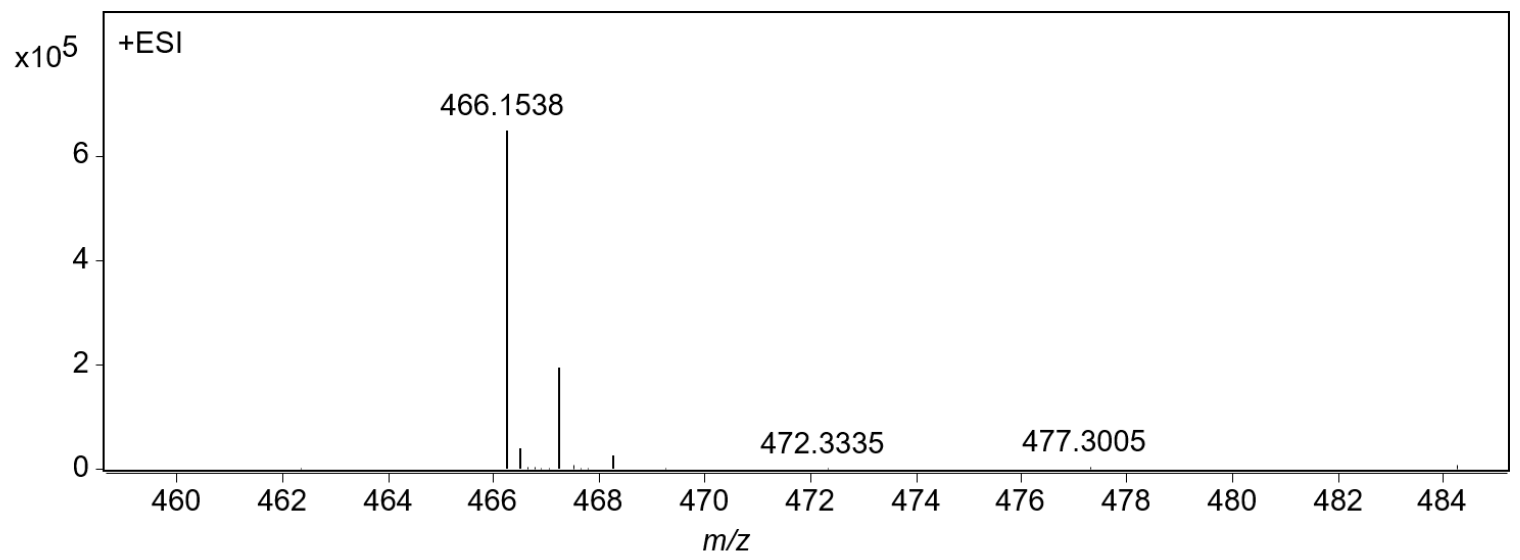

Figure S3. HR-ESIMS spectrum of 5. 


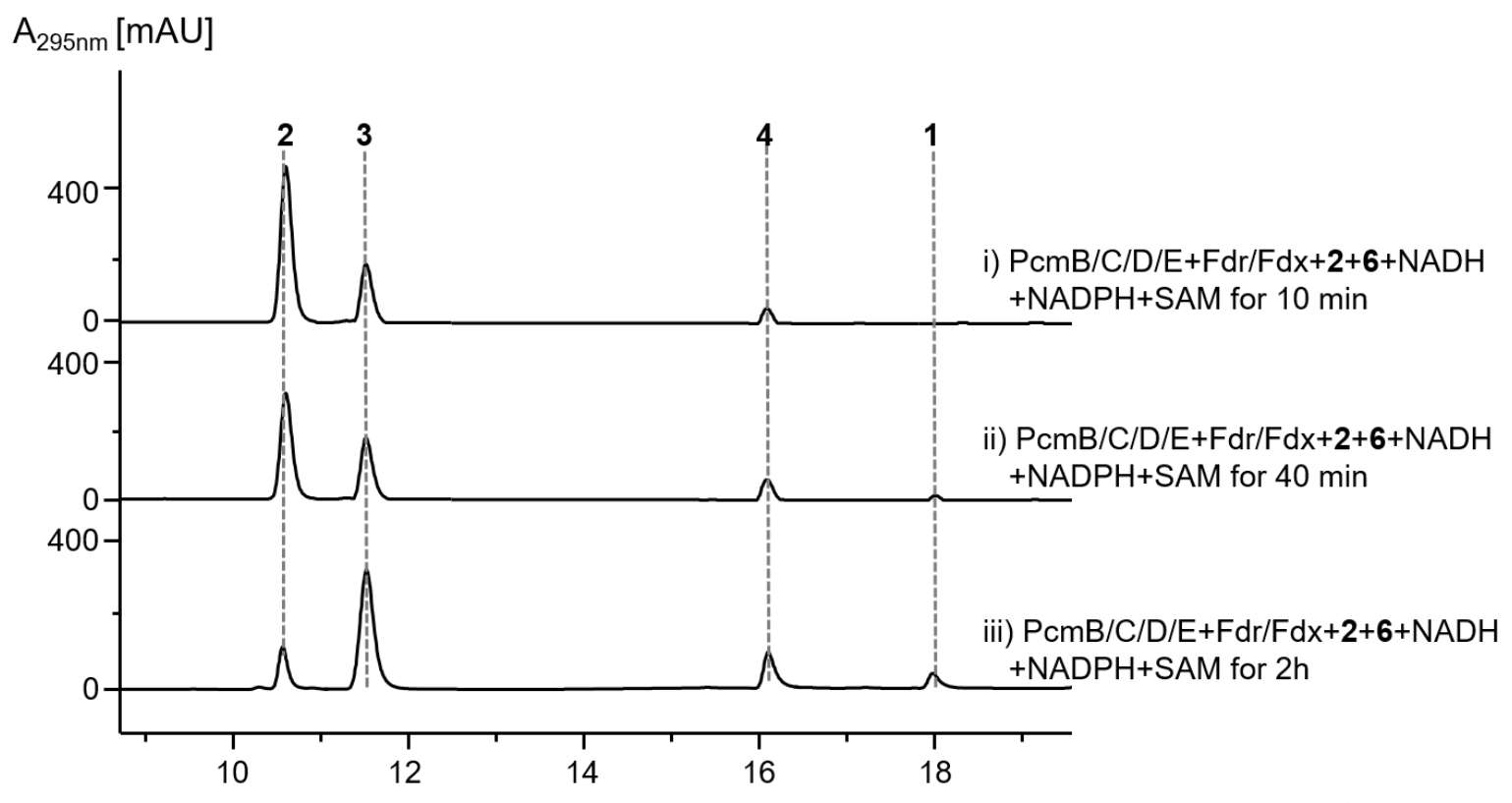

Figure S4. The time-course of the one-pot enzymatic reaction.
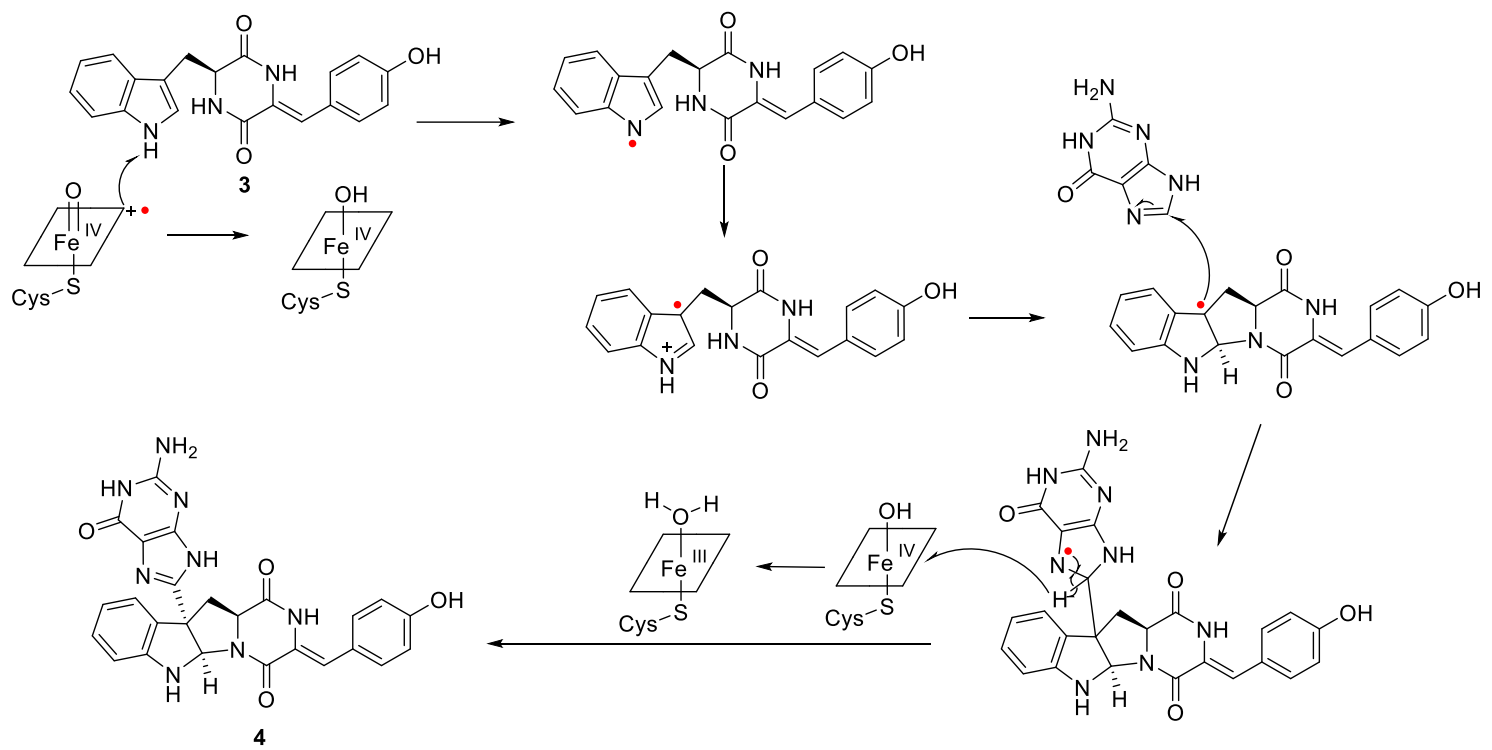

Figure S5. Proposed catalytic mechanism for PcmD. ${ }^{8}$ 


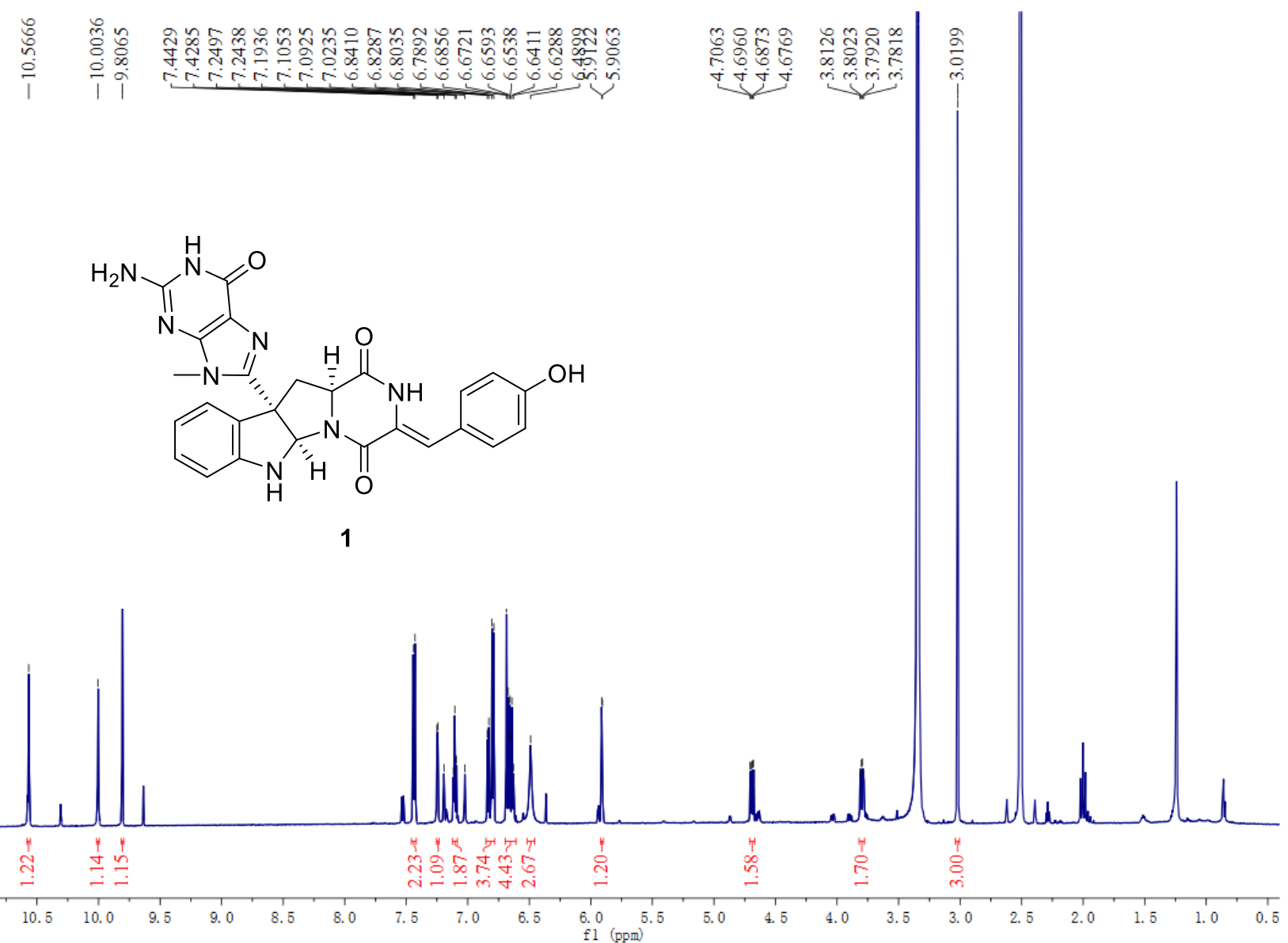

Figure S6. ${ }^{1} \mathrm{H}$ NMR spectrum of 1 in DMSO- $d_{6}$ at $600 \mathrm{MHz}$.

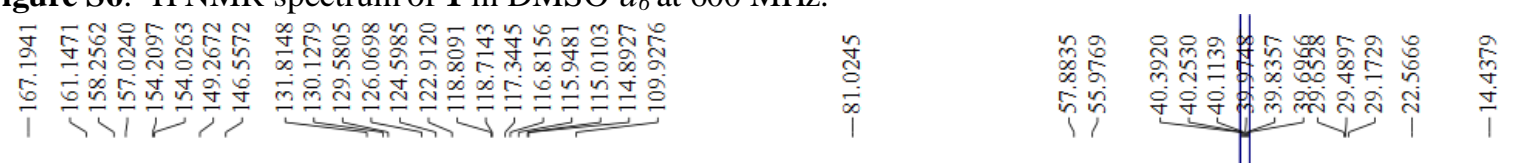

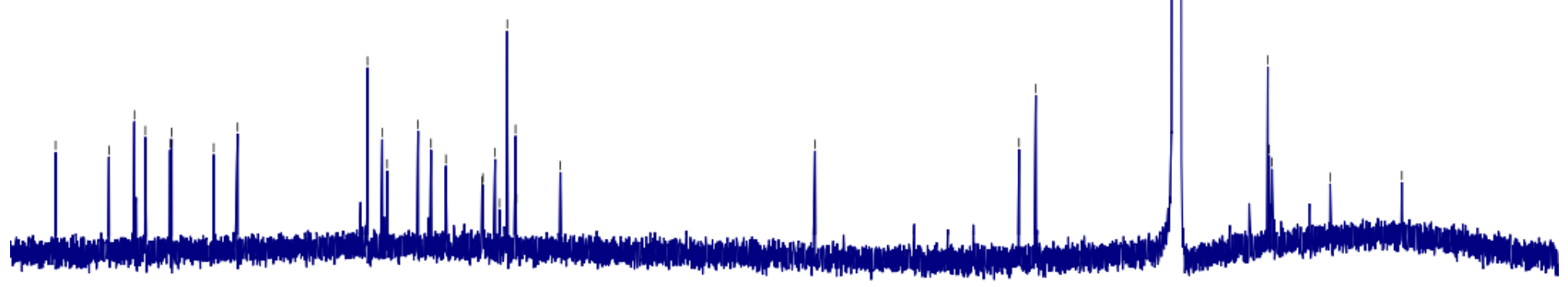

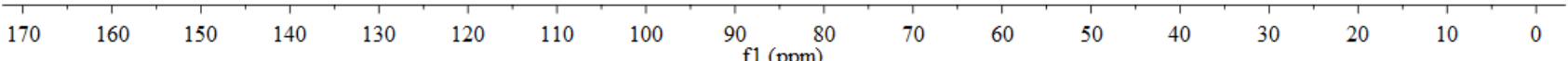

Figure S7. ${ }^{13} \mathrm{C}$ NMR spectrum of $\mathbf{1}$ in DMSO- $d_{6}$ at $150 \mathrm{MHz}$. 


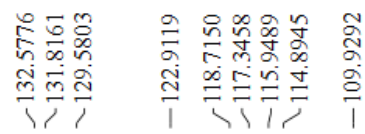

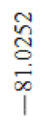

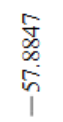<smiles>Cn1cnc2c(=O)[nH]c(N)nc21</smiles>

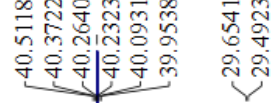<smiles>O=C1N/C(=C\c2ccc(O)cc2)C(=O)N2C(I)CCC12</smiles>

1
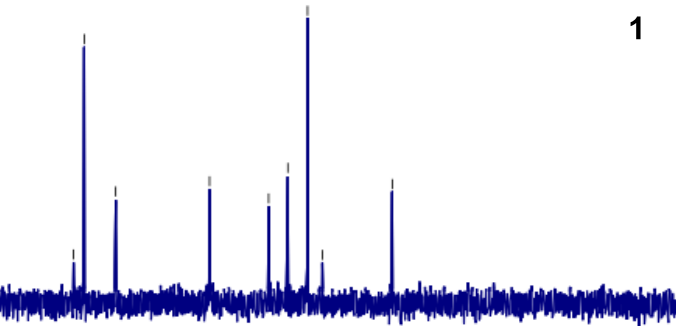

$\begin{array}{llllllllllllllllllllllll}135 & 130 & 125 & 120 & 115 & 110 & 105 & 100 & 95 & 90 & 85 & \begin{array}{l}80 \\ \mathrm{f} 1(\mathrm{ppm})\end{array} & 70 & 65 & 60 & 55 & 50 & 45 & 40 & 35 & 30 & 25 & 20\end{array}$

Figure S8. DEPT 135 spectrum of 1 in DMSO- $d_{6}$.

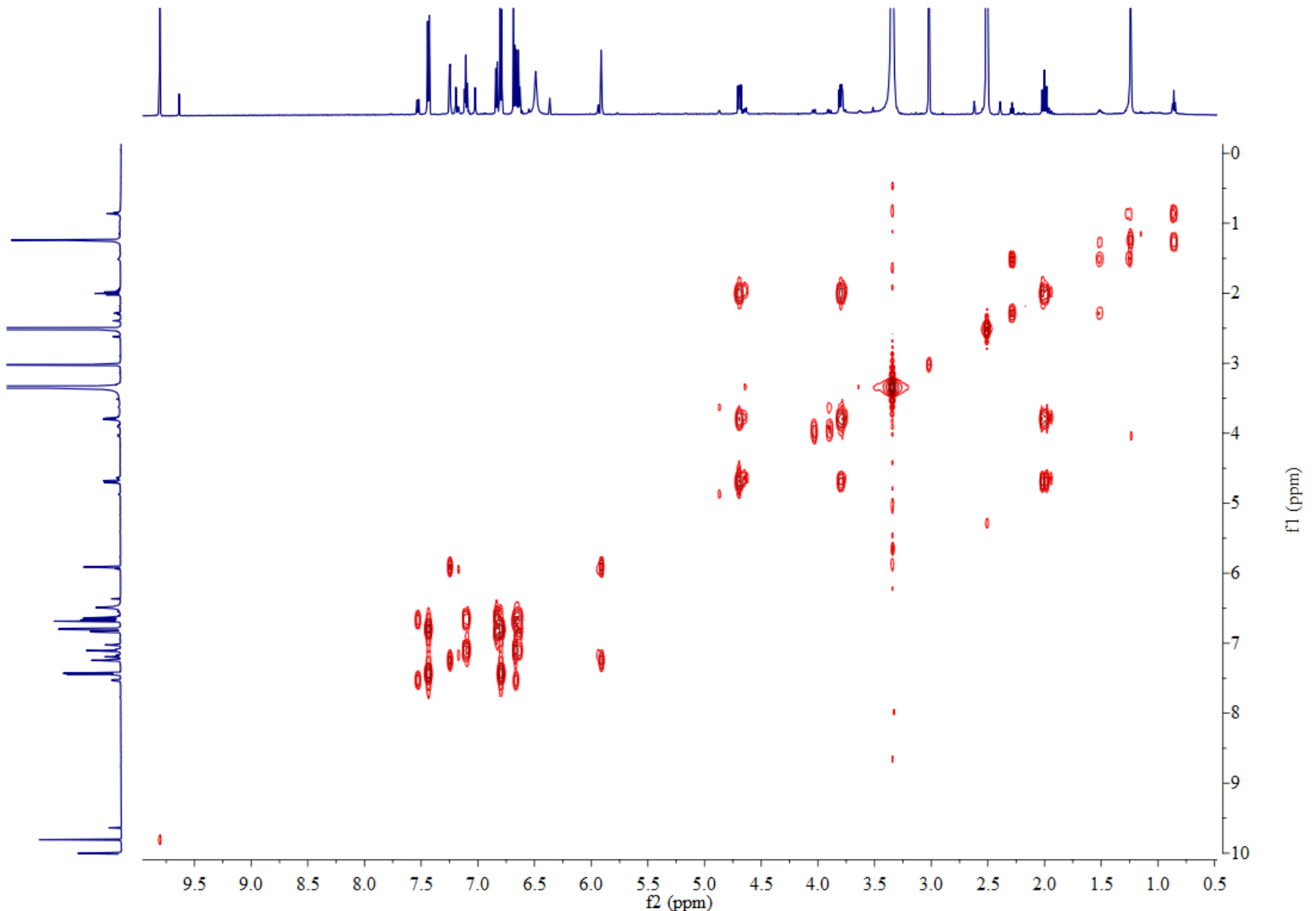

Figure S9. ${ }^{1} \mathrm{H}-{ }^{1} \mathrm{H}$ COSY NMR spectrum of 1 in DMSO- $d_{6}$. 


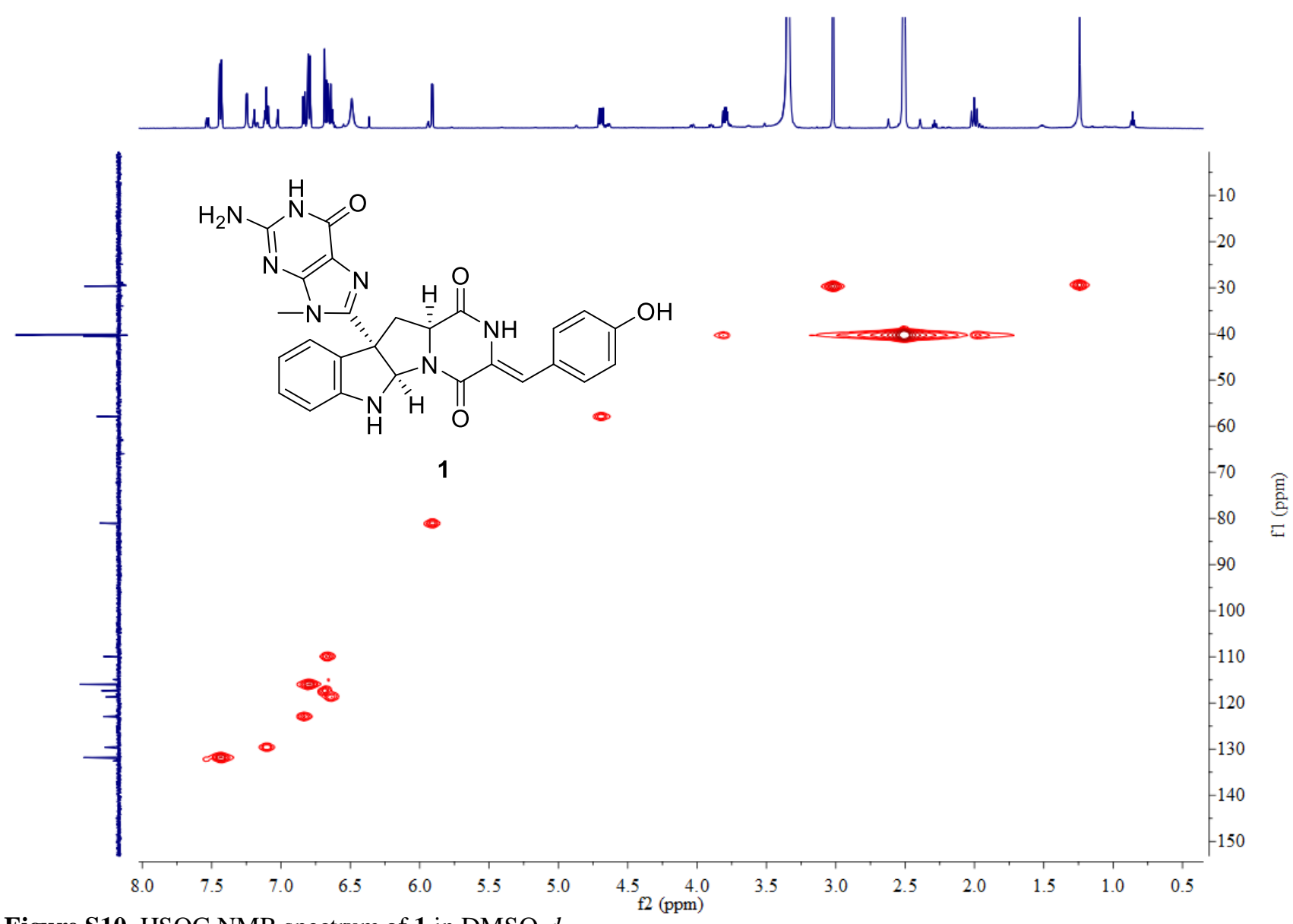

Figure S10. HSQC NMR spectrum of 1 in DMSO- $d_{6}$.

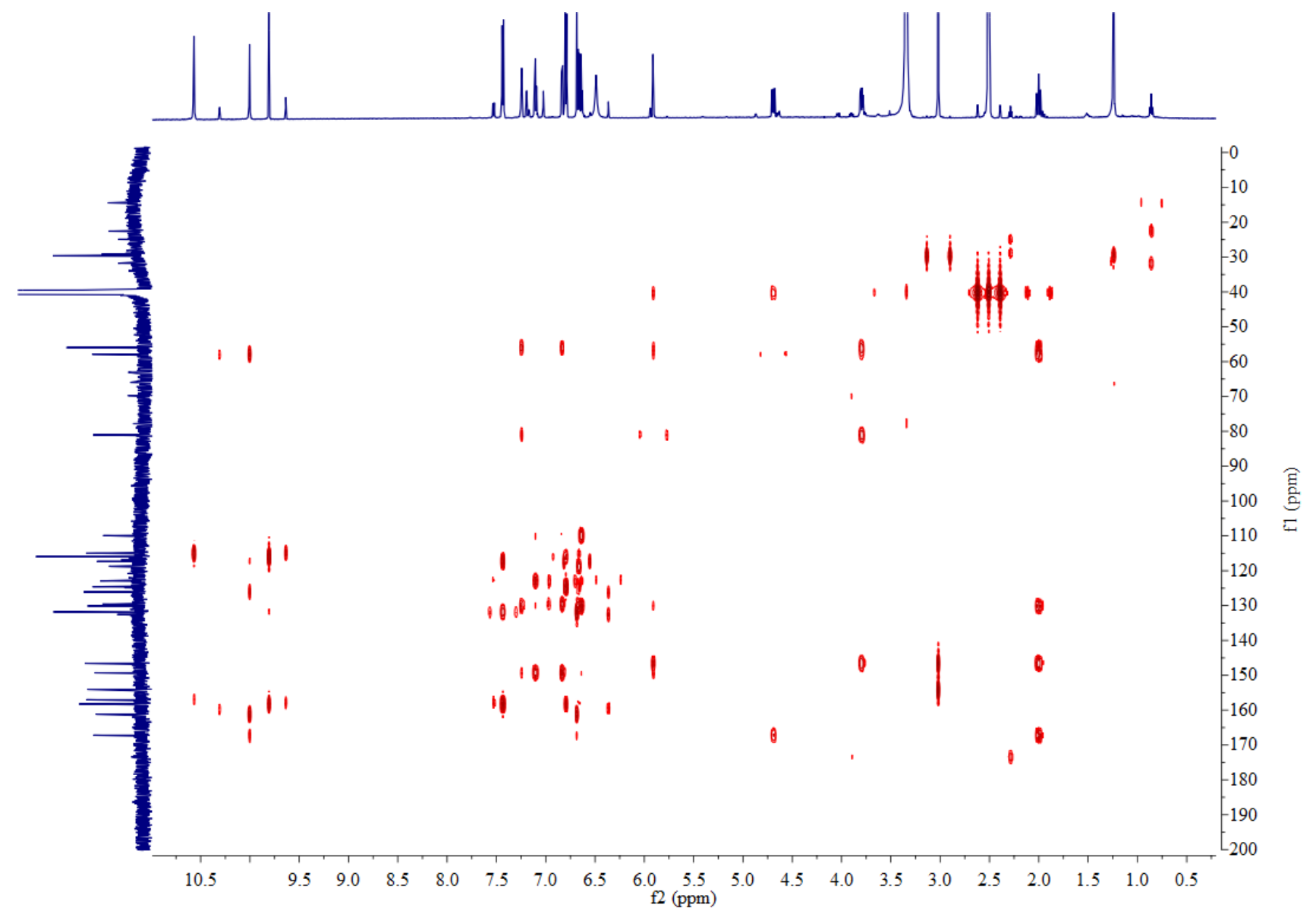

Figure S11. HMBC NMR spectrum of 1 in DMSO- $d_{6}$. 


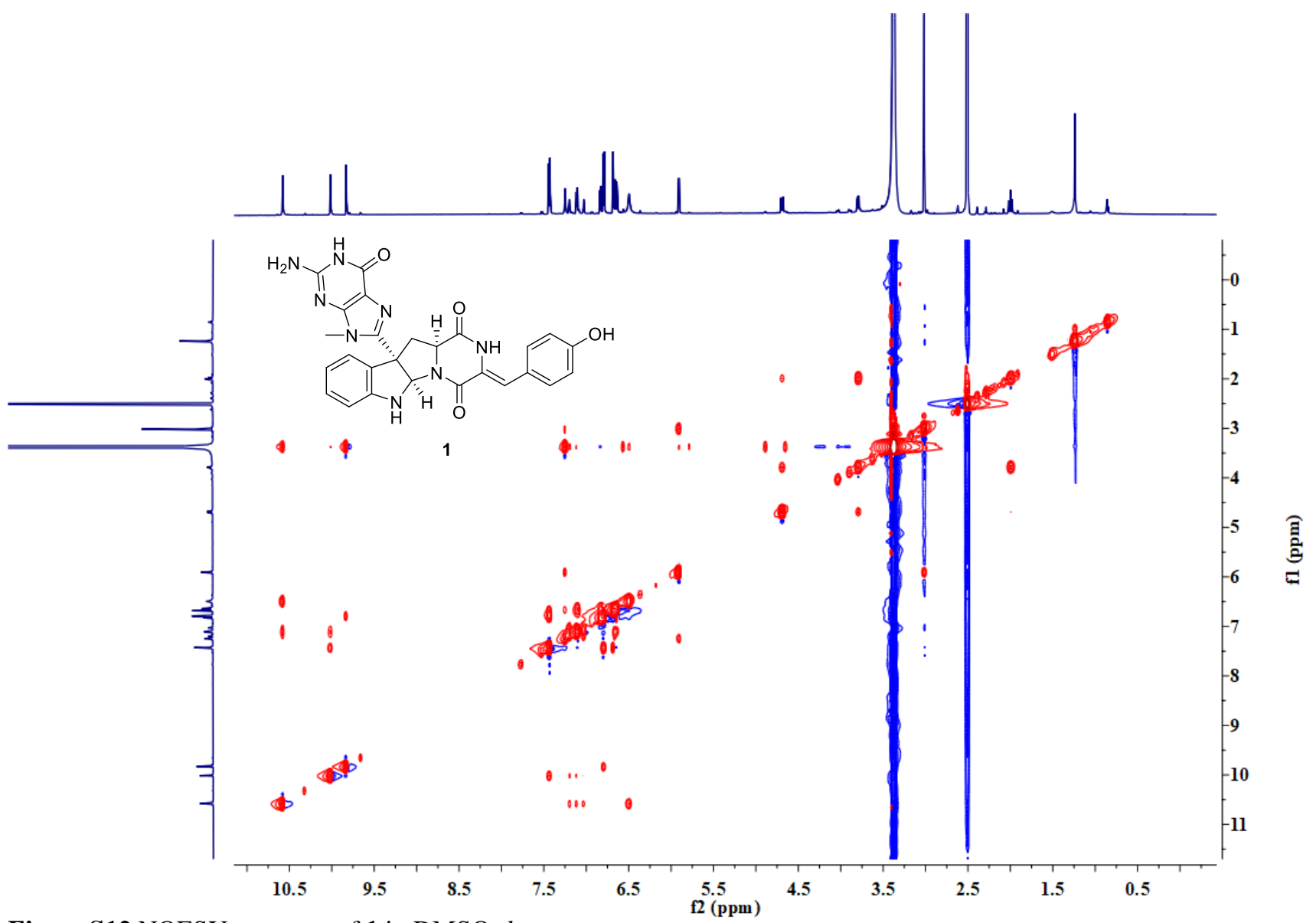

Figure S12.NOESY spectrum of 1 in DMSO- $d_{6}$.

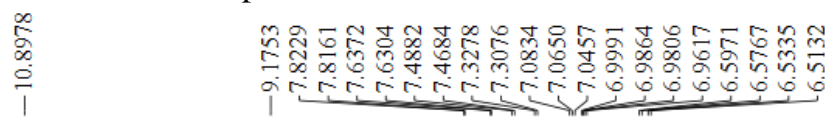<smiles>O=C1NC(CC2CNc3ccccc32)C(=O)NC1Cc1ccc(O)cc1</smiles>
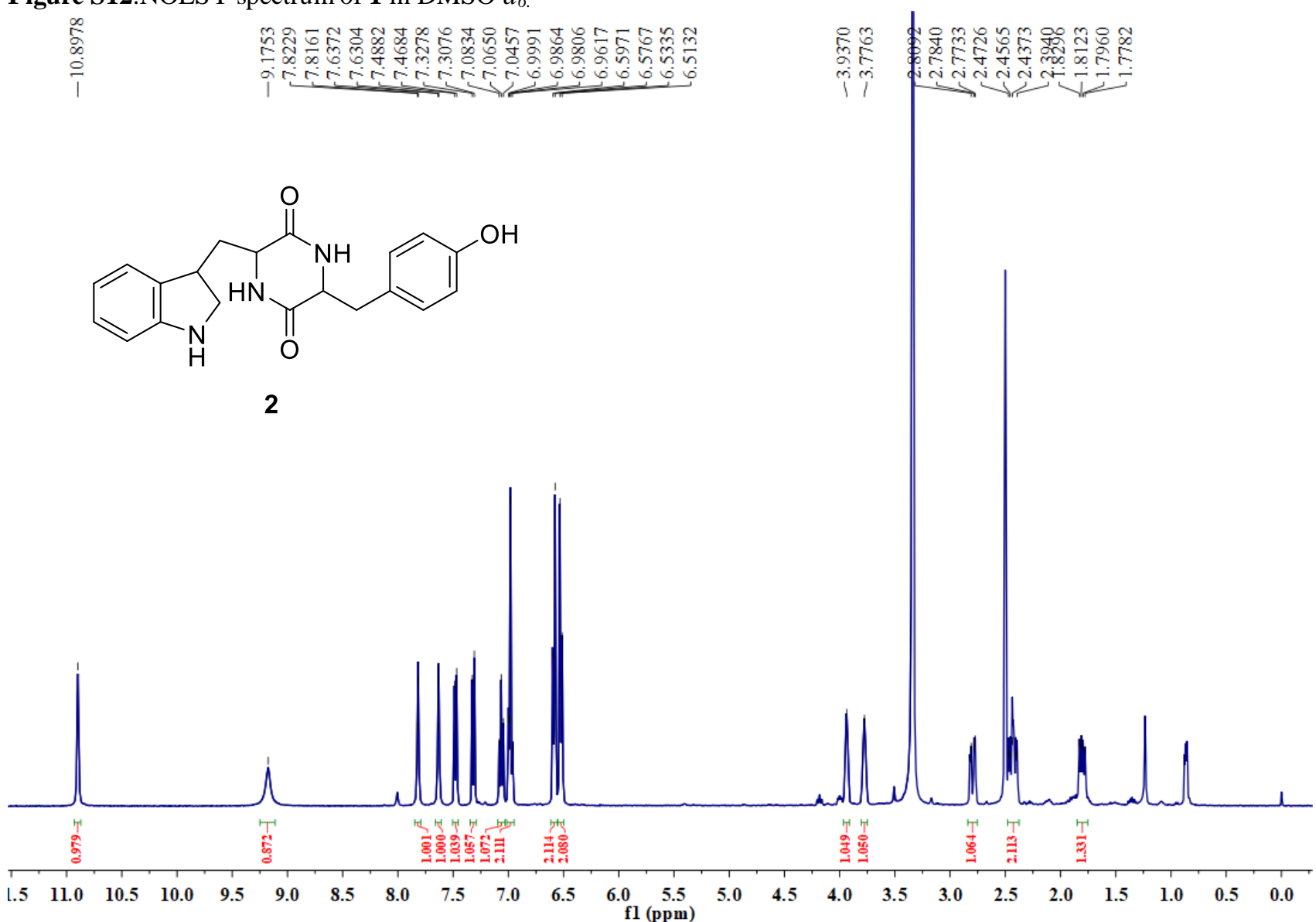

Figure S13. ${ }^{1} \mathrm{H}$ NMR spectrum of 2 in DMSO- $d_{6}$ at $400 \mathrm{MHz}$. 
<smiles>O=C1NC(CC2CNc3ccccc32)C(=O)N/C1=C\c1ccc(O)cc1</smiles>

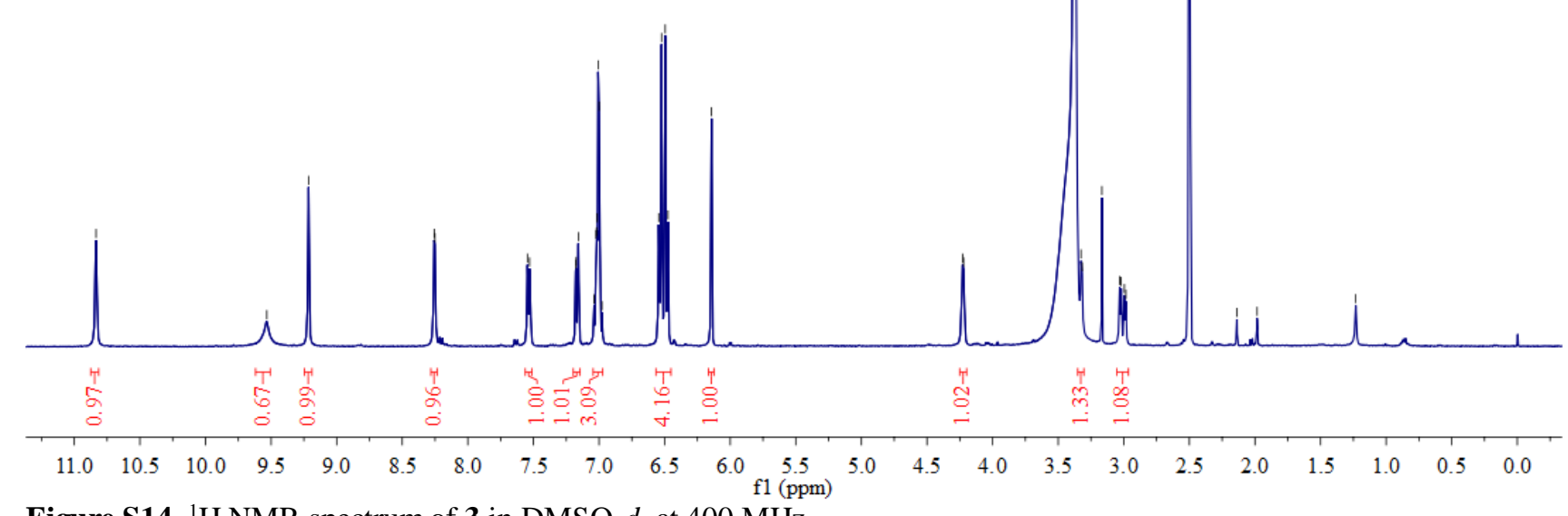

Figure S14. ${ }^{1} \mathrm{H}$ NMR spectrum of 3 in DMSO- $d_{6}$ at $400 \mathrm{MHz}$.

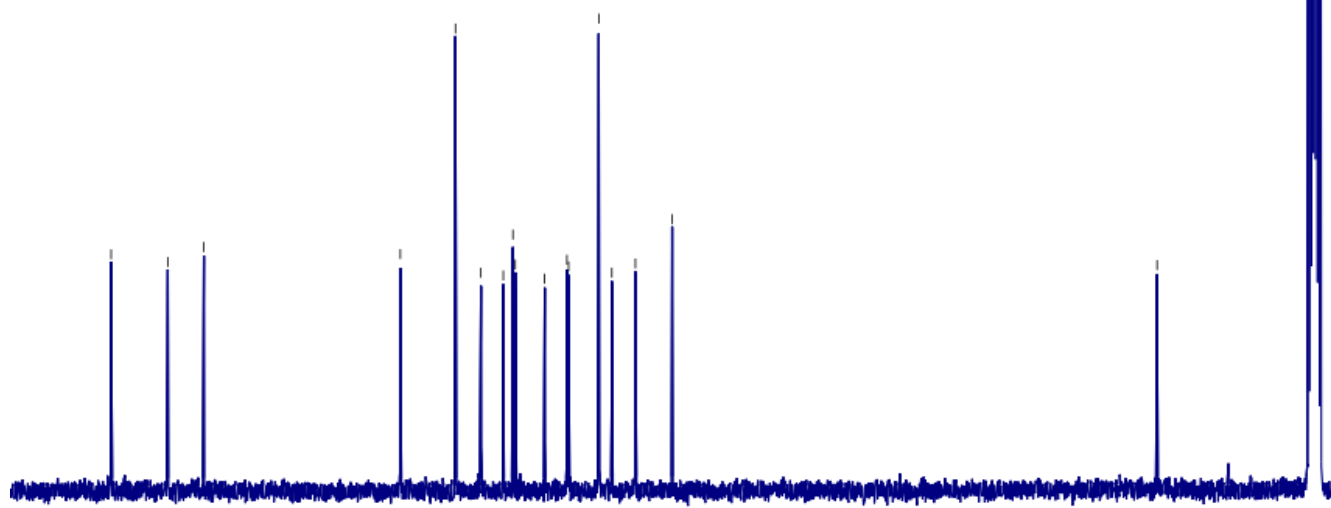

Figure S15. ${ }^{13} \mathrm{C}$ NMR spectrum of 3in DMSO- $d_{6}$ at $100 \mathrm{MHz}$. 


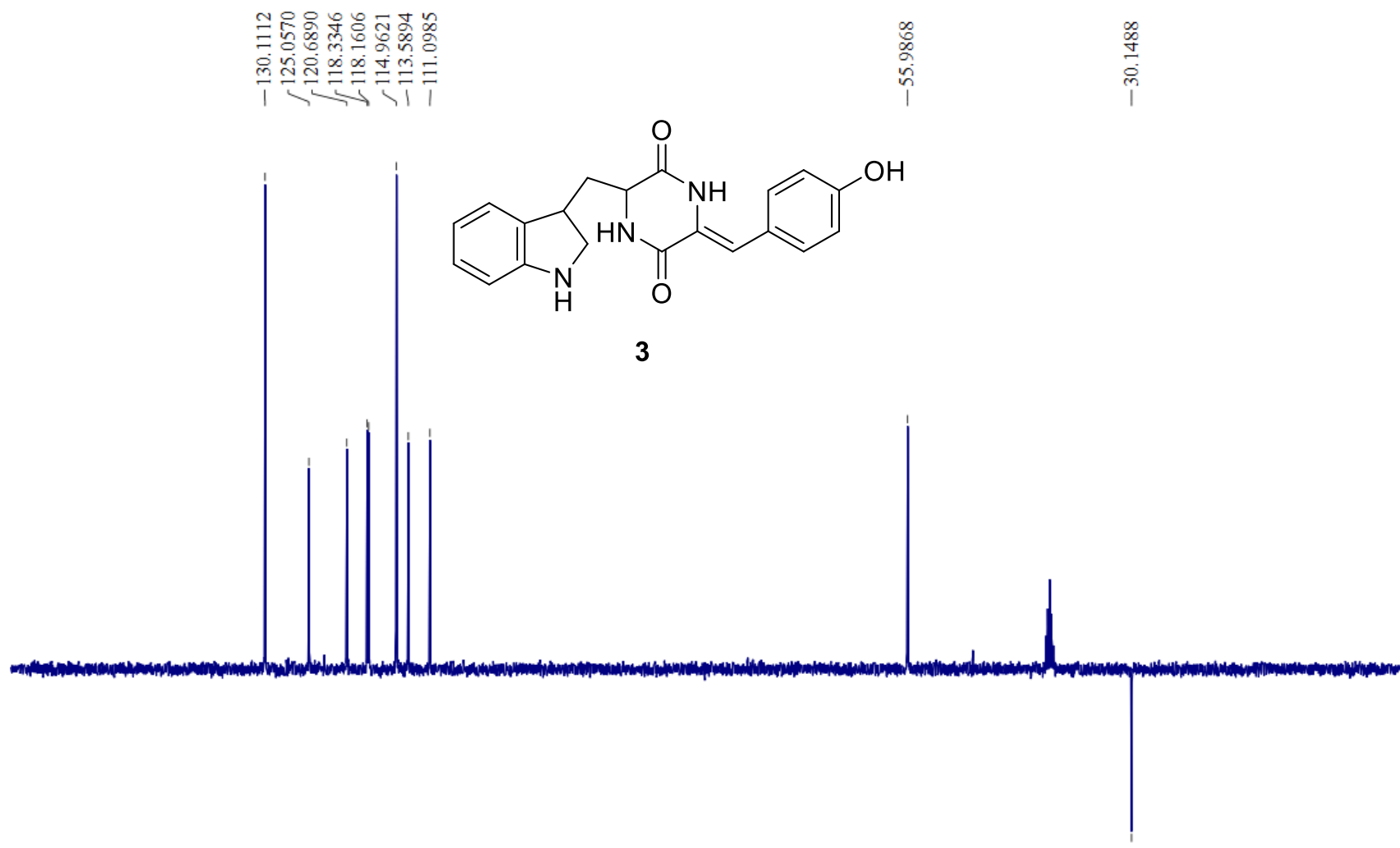

$110 \quad 100$

f1 $(\mathrm{ppm})$

Figure S16. DEPT 135 spectrum of $\mathbf{3}$ in DMSO- $d_{6}$.

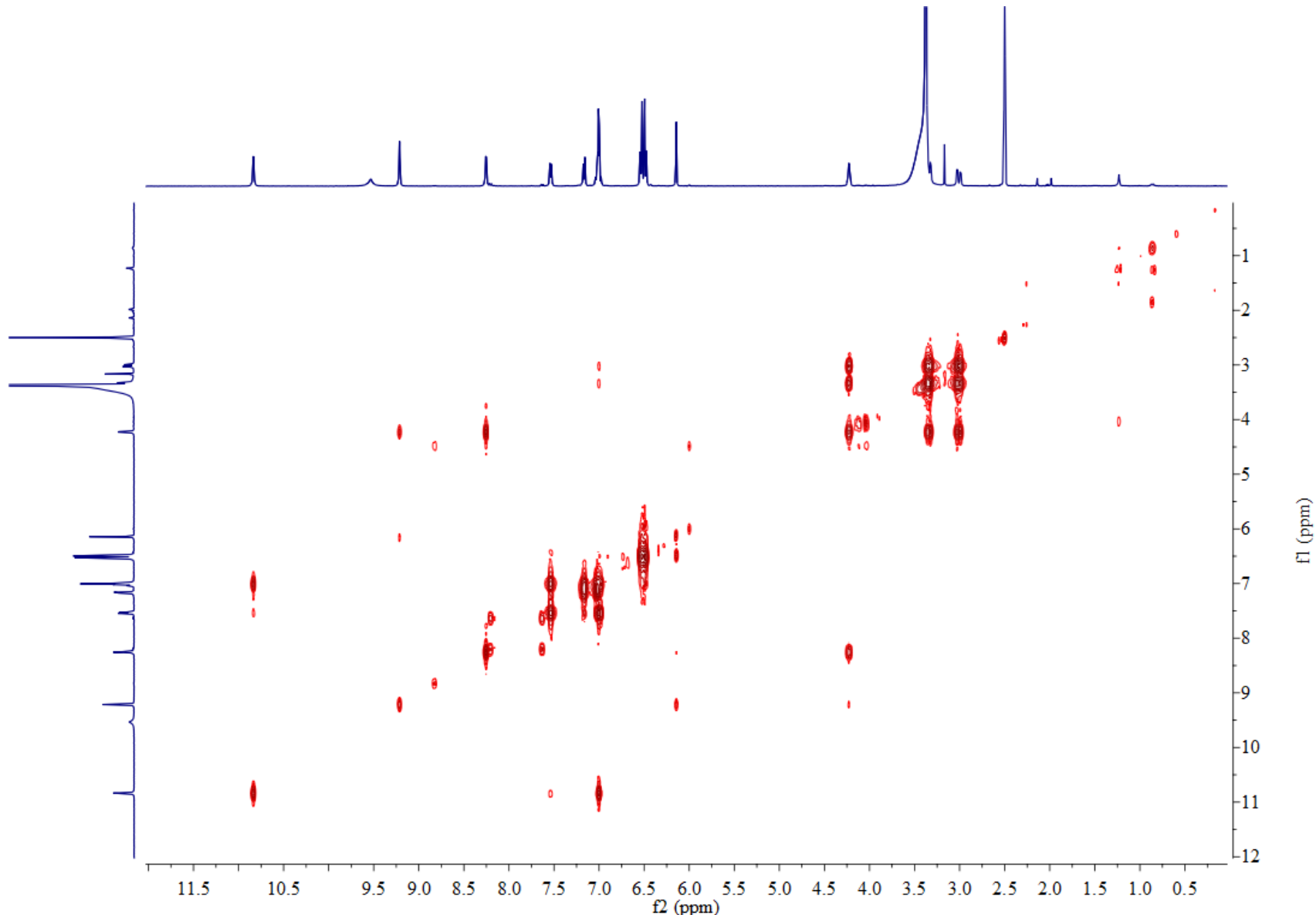

Figure S17. ${ }^{1} \mathrm{H}-{ }^{1} \mathrm{H}$ COSY NMR spectrum of $\mathbf{3}$ in DMSO- $d_{6}$. 


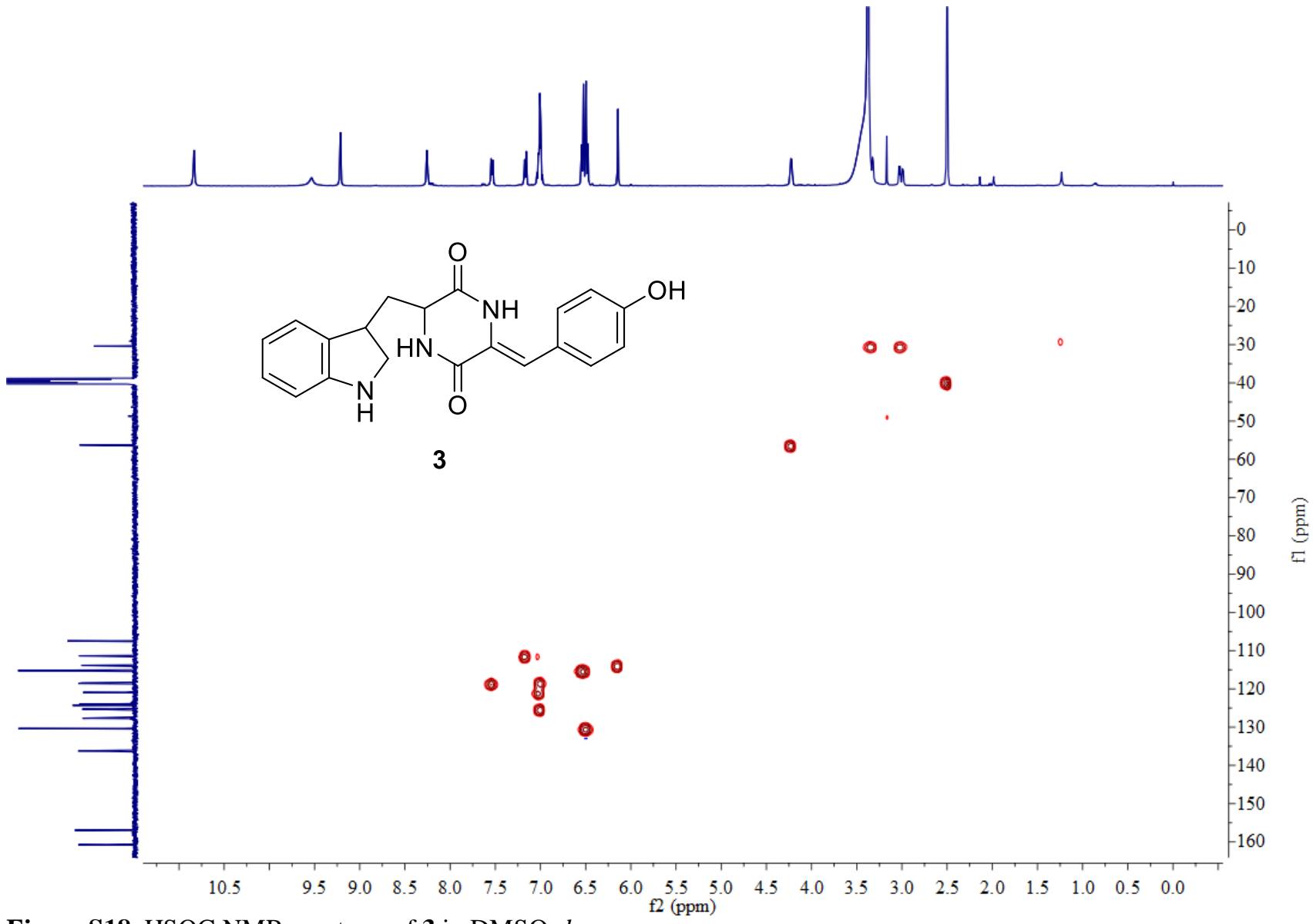

Figure S18. HSQC NMR spectrum of $\mathbf{3}$ in DMSO- $d_{6}$.

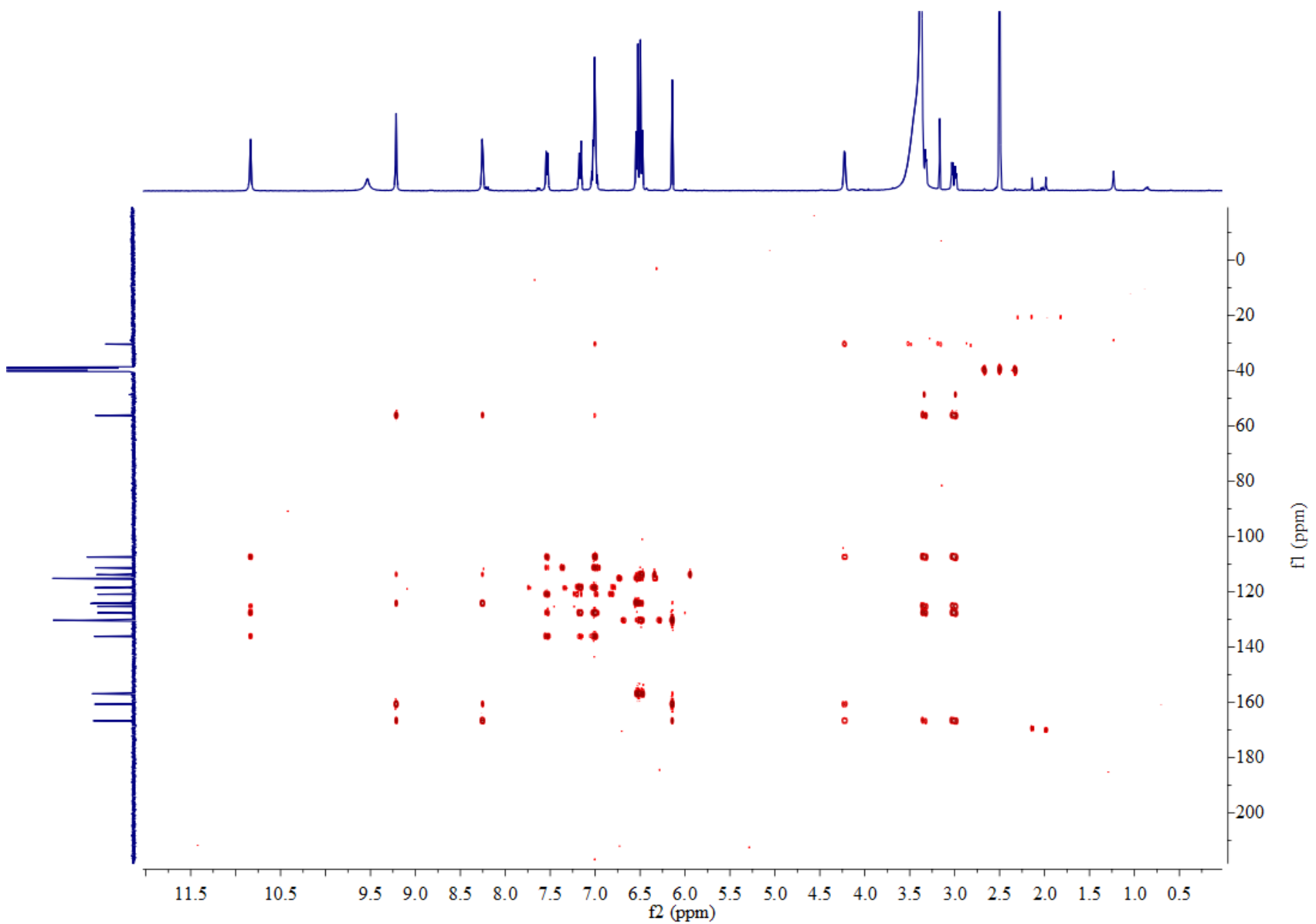

Figure S19. HMBC NMR spectrum of $\mathbf{3}$ in DMSO- $d_{6}$. 


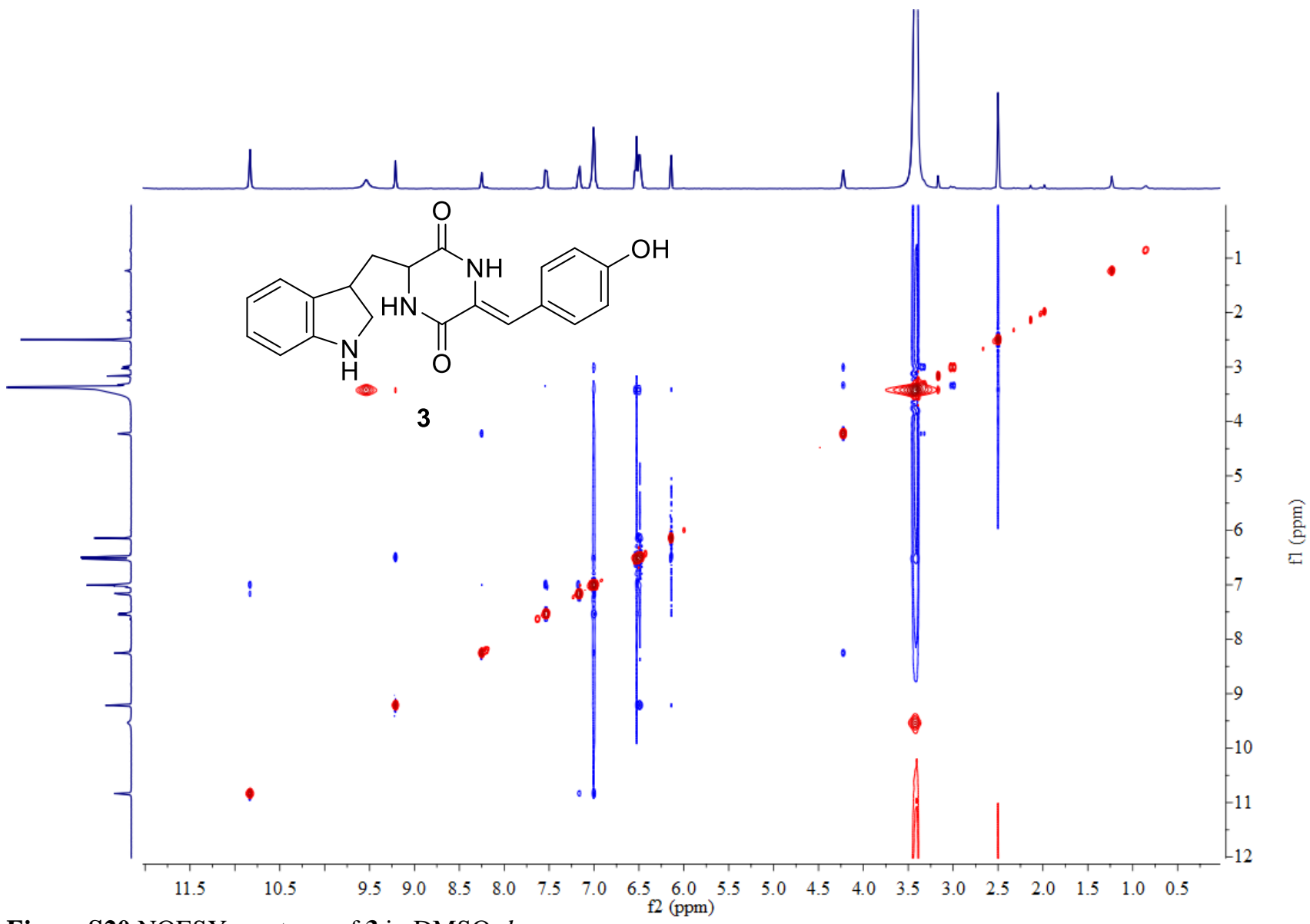

Figure S20.NOESY spectrum of 3 in DMSO- $d_{6}$.

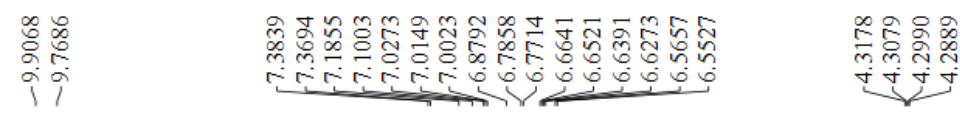<smiles>Nc1nc2[nH]c([C@@]3(c4ccccc4N)CC4C(=O)N/C(=C\c5ccc(O)cc5)C(=O)N43)nc2c(=O)[nH]1</smiles>

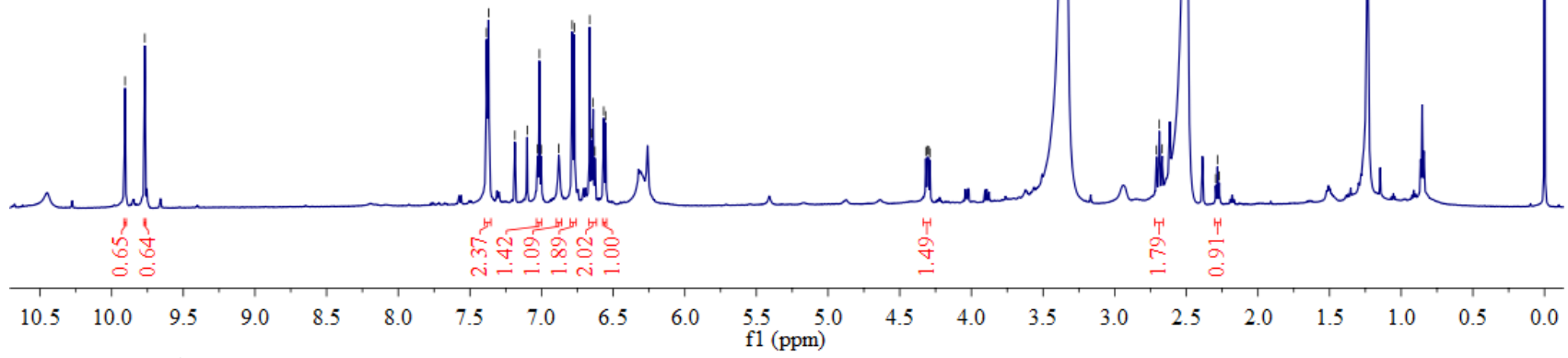

Figure S21. ${ }^{1} \mathrm{H}$ NMR spectrum of 4 in DMSO- $d_{6}$ at $600 \mathrm{MHz}$. 
<smiles>Nc1nc2[nH]cnc2c(=O)[nH]1</smiles><smiles></smiles>

4
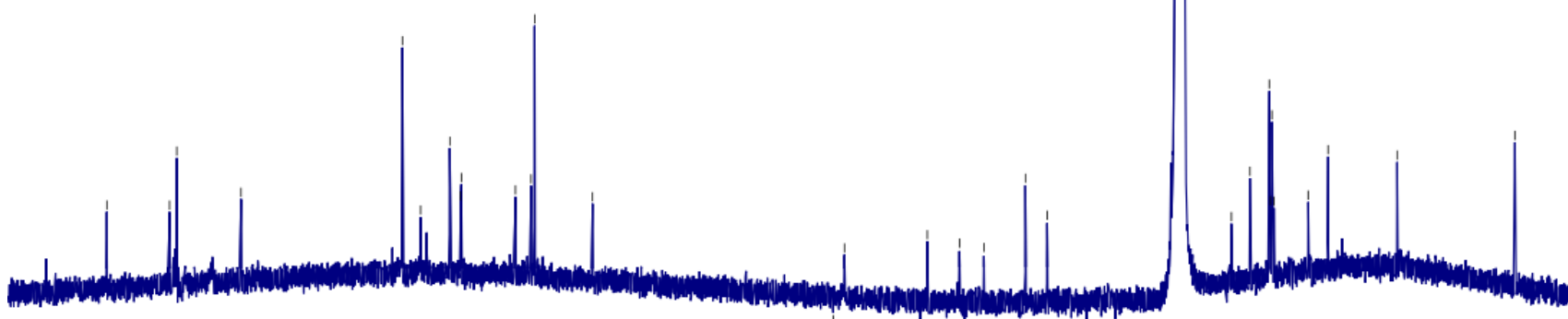

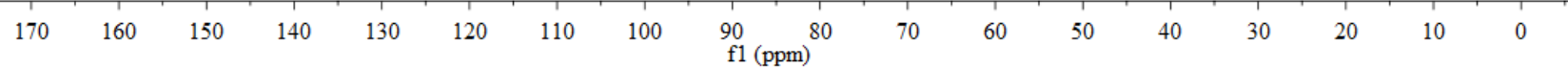

Figure S22. ${ }^{13} \mathrm{C}$ NMR spectrum of 4 in DMSO- $d_{6}$ at $150 \mathrm{MHz}$.

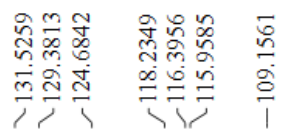

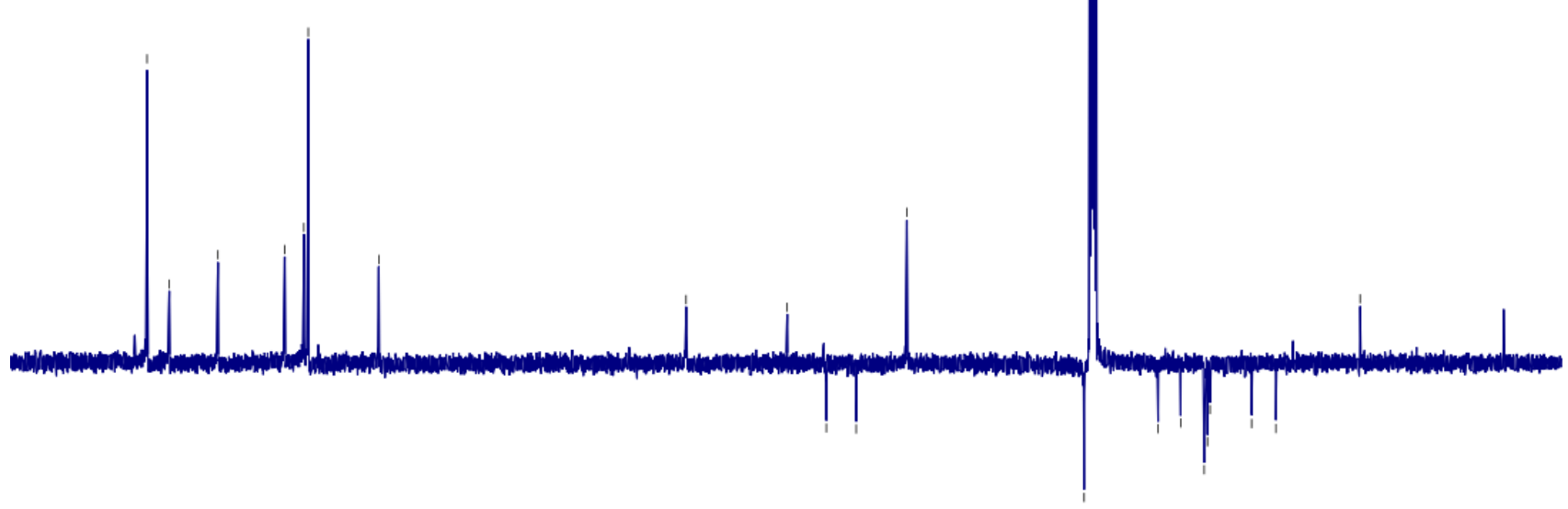

$\begin{array}{llllllllllllllll}140 & 135 & 130 & 125 & 120 & 115 & 110 & 105 & 100 & 95 & 90 & 85 & 80 & 75 & 70 & 6\end{array}$

Figure S23. DEPT 135 spectrum of 4 in DMSO- $d_{6}$ 


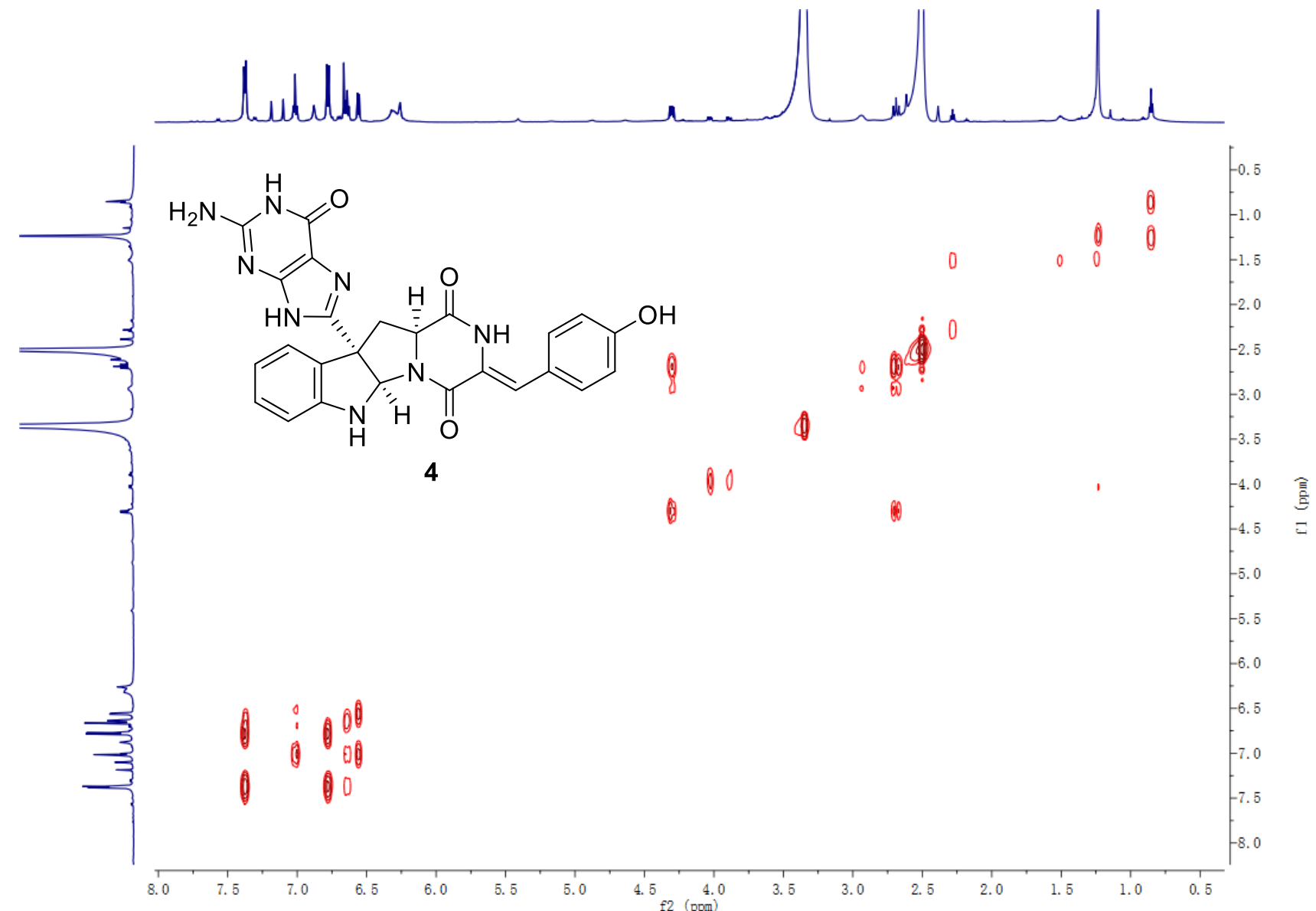

Figure S24. ${ }^{1} \mathrm{H}^{-1} \mathrm{H}$ COSY NMR spectrum of 4 in DMSO- $d_{6 .}^{\mathrm{f2}}$ (ppm)

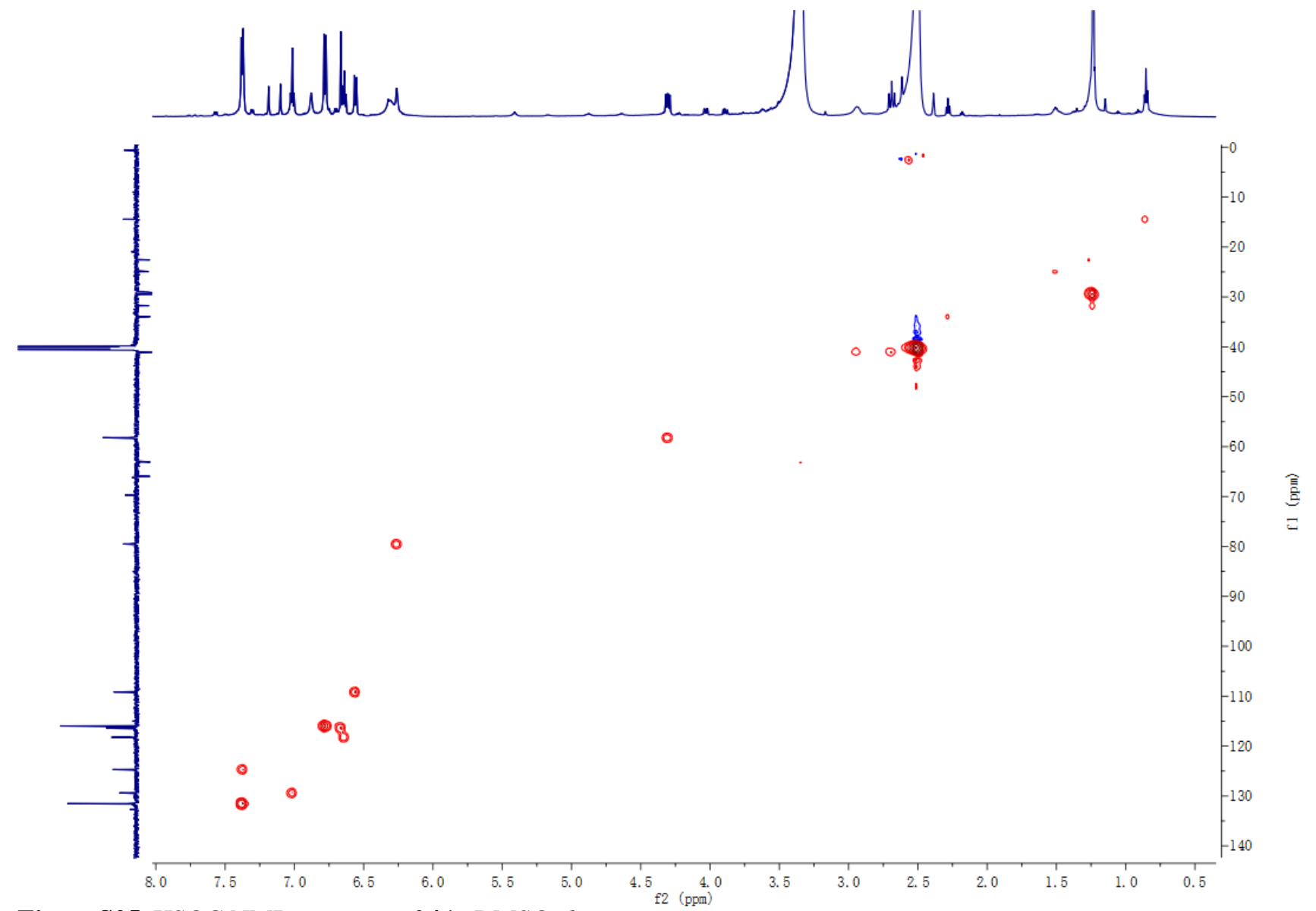

Figure S25. HSQC NMR spectrum of $\mathbf{4}$ in DMSO- $d_{6}$. 


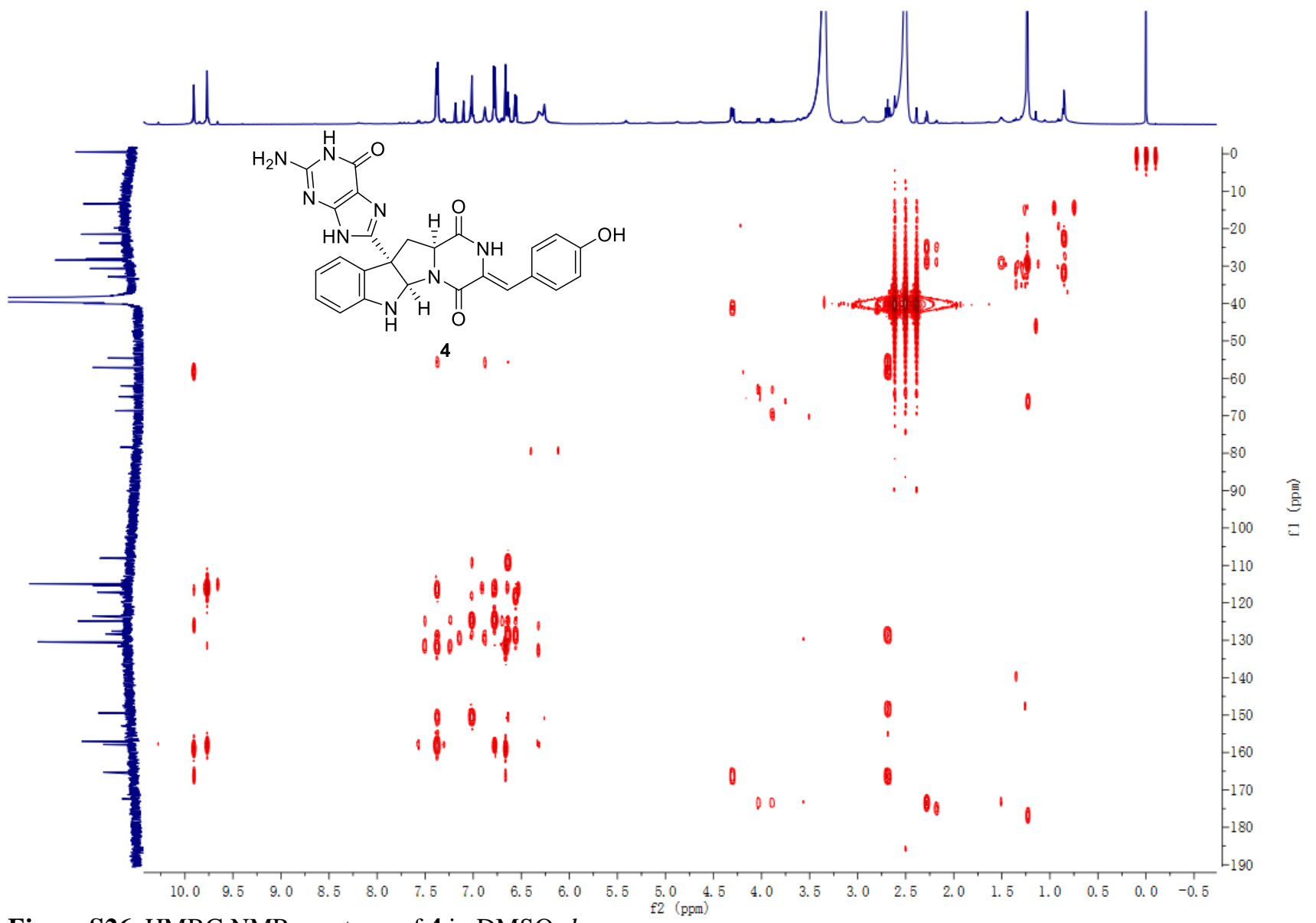

Figure S26. HMBC NMR spectrum of $\mathbf{4}$ in DMSO- $d_{6}$

\section{Reference}

[1] M. Beye, A. Poch, C. Burgtorf, R. F. A. Moritz, H. Lehrach, Genomics 1998, 49, 317.

[2] D. A. Hopwood, M. J. Bibb, K. F. Chater, T. Kieser, C. J. Bruton, H. M. Kieser, D. J. Lydiate, C. P. Smith, J. M. Ward, H. Schrempf, Genetic Manipulation of Streptomyces-A Laboratory Manual, Cold Spring Harbor Laboratory Press, New York 1985.

[3] L. Li, Z. Xu, J. Wu, Y, Zhang, X. He, T. M. Zabriskie, Z. Deng, Chembiochem. 2008, 9, 1286.

[4] Shi, J.; Liu, C. L.; Zhang, B.; Guo, W. J.; Zhu, J. P.; Chang, C. Y.; Zhao, E. J.; Jiao, R. H.; Tan, R. X.; Ge, H. M. Chem.Sci. 2019, 10, 4839.

[5] M.R. Green, J. Sambrook, Molecular Cloning: A Laboratory Manual 4th edn (Cold Spring Harbor Laboratory Press, 2012).

[6] M. Bierman, R. Logan, K. O’Brien, E. T. Seno, R. N. Rao, B. E. Schoner, Gene 1992, 116, 43.

[7] Z. Zhao, T. Shi, M. Xu, N. L. Brock, Y. L. Zhao, Y. Wang, Z. Deng, X. Pang, M. Tao, Org. Lett. 2016, $18,572$.

[8] Tian, W. Y.; Sun, C. H.; Zheng, M.; Harmer, J. R.; Yu, M. J.; Zhang, Y. A.; Peng, H. D.; Zhu, D. Q.; Deng, Z. X.; Chen, S. L.; Mobli, M.; Jia, X. Y.; Qu, X. D. Nat. Commun. 2018, 9, 4428. 